\title{
From platform top to adjacent deep sea: New source-to-sink insights into carbonate sediment production and transfer in the SW Indian Ocean (Glorieuses archipelago)
}

\author{
Jorry Stephan 1, ${ }^{*}$, Jouet Gwenael ${ }^{1}$, Edinger Evan N. ${ }^{2}$, Toucanne Samuel ${ }^{1}$, Counts John W. ${ }^{3}$, \\ Miramontes Elda ${ }^{4}$, Courgeon Simon ${ }^{5}$, Riveiros Natalia Vázquez ${ }^{1}$, Le Roy Pascal ${ }^{6}$, Camoin Gilbert F. ${ }^{7}$
}

1 Ifremer, Unité Géosciences Marines, Technopôle la Pointe du Diable, 29280 Plouzané, France

2 Memorial University, Departments of Geography and Biology, St. Johns, Newfoundland, Canada

3 University of College Dublin, School of Earth Sciences, Belfield, Dublin 4, Ireland

4 University of Bremen, Bibliothekstraße 1, 28359 Bremen, Germany

5 University of Geneva, Department of Earth Sciences, 13 rue des Maraîchers, 1205 Geneva, Switzerland

6 Université de Brest, CNRS, IUEM, UMR 6538 Géosciences Océan, 29290 Plouzané, France

${ }^{7}$ Aix Marseille Université, CNRS, IRD, Collège de France, CEREGE, Technopôle Environnement, Arbois-Méditerranée BP80, 13545 Aix en Provence, France

* Corresponding author : Stephan Jorry, email address : stephan.jorry@ifremer.fr

\begin{abstract}
:
Over the past ten years, a huge amount of source-to-sink studies have aimed to unravel the tectonic, climatic and other processes that shape the landscape from mountains to the deep ocean. Interestingly, these studies have been mainly dedicated to siliciclastic or mixed systems, for which the connection between drainage basins, continental shelves, slope and basin environments are often well constrained. Here we present a study focusing on a source-to-sink study dedicated to a pure carbonate system, located in the SW Indian Ocean (Glorieuses archipelago). Extensive field sampling and geophysical acquisition across the carbonate platform have allowed us to estimate the composition, the lateral variability, and volumes of neritic sands deposited on the platform top. Additional seismic and bathymetric surveys across the platform interior illustrate the presence of plurimetric sandy bodies deposited along the leeward platform edge, corresponding to the export of carbonate sediments from the platform top toward the platform edge, under the influence of dominant currents and wind-driven processes. High-resolution seismic, bathymetric data and sediment cores acquired along the leeward slope and basin adjacent to the carbonate platform highlight the presence of channel-levee complexes and turbiditic lobes, which have accumulated on the seafloor on top of a 250 m-thick sedimentary basin at 2000-3400 m water depth. Our study points out that carbonate sands and aragonitic mud produced on the platform top during the Holocene have been shed to the adjacent basin. We also demonstrate that this routing system was active at least throughout the last three glacial/interglacial cycles. This study has important consequences for our understanding of carbonate sedimentation processes occurring in the vicinity of isolated carbonate platforms: 1 - it highlights the role of oceanographic conditions in the distribution of sediment on a platform top and its export along the platform edge and the adjacent basin; 2 - it contributes to quantify the productivity of a carbonate platform as well as its sediment storage capacity; 3 - a first estimate of a carbonate source-to-sink system is proposed, demonstrating that $0,57 \mathrm{~km} 3$ of sediments have been
\end{abstract}


produced during the Holocene, $0,3 \mathrm{~km} 3$ being presently stored on the platform, and the remaining having been exported to the deep basin.

\section{Highlights}

- First study to propose a carbonate source-to-sink budget, from platform top to adjacent basin. Neritic sands produced on platform top are mainly stored along the leeward platform edge. Carbonate sediments are exported in the basin through channel-levee complexes. This carbonate routine systems was active during past glacial/interglacial cycles.

Keywords : Carbonate platform, coral reef, calciturbidite, aragonite, carbonate budget, Indian Ocean 


\section{Introduction}

Other than fluvial sediment, calcium carbonate $\left(\mathrm{CaCO}_{3}\right)$ is the greatest source of sediment in the present-day ocean, estimated to be about 5 bt per year, of which about 3 bt accumulate in sediments, while the other $40 \%$ is dissolved (Milliman, 1993). Therefore, the burial of $\mathrm{CaCO}_{3}$ and organic carbon in marine sediments is the largest sink for carbon from Earth's surface environment (Falkowski et al., 2000; Milliman, 1993; Milliman and Droxler, 1996). Unlike fluvial sediments, modern carbonates accumulate in neritic and pelagic settings. The estimated present-day carbonate accumulation $\left(32 \times 10^{12}\right.$ moles. $\left.\mathrm{yr}^{-1}\right)$ is 1.5 times the sum of calcium influx from rivers and the amount estimated to weather out of mid-ocean ridge crests $\left(21 \times 10^{12}\right.$ moles.yr $\left.{ }^{-1}\right)($ Milliman and Droxler, 1995). Although this difference rests upon some uncertainties, the much greater rates of carbonate production and accumulation in the neritic environment suggest that steady state becomes ambiguous when sea level changes (Milliman and Droxler, 1995).

Biogenic calcification is an important process in the building of coral reefs and for the supply of carbonate sands to coastal lagoons (Kangwe, 2006). The contribution of carbonates to the sedimentary composition of the marine environments is particularly significant in the West Indian Ocean (Kangwe, 2006; Rees et al., 2005), with approximately $50 \%$ of all $\mathrm{CaCO}_{3}$ stored in shallow coastal regions and continental shelves as well as in coral reef environments (Andersson and Gledhill, 2013). Many studies have demonstrated that an appreciable portion of neritic carbonates produced on banks and shelves (characterized by rapid production of metastable aragonite and magnesian calcite) is exported to the deep sea by nepheloid plumes (Wilson and Roberts, 1995) and gravity flows (Andresen et al., 2003; Droxler and Schlager, 
1985; Glaser and Droxler, 1993; Jorry et al., 2008, 2010; Mullins et al., 1984; Schlager et al., 1994; Webster et al., 2012). Since 20 years ago, the seismic architecture of neritic-dominated carbonate basins has been largely unexplored. The first evidence came from core, logging and high-resolution seismic data from ODP Leg 166 (Eberli et al., 1997a, 1997b), where MioceneLower Pliocene calciturbidites are arranged into mounded lobes with feeder channels along Great and Little Bahama Bank (Betzler et al., 1999; Bornhold and Pilkey, 1971; Crevello and Schlager, 1980). Recently, new investigations along the western slope of Great Bahama Bank have pointed out notable differences when comparing carbonate gravity systems to siliciclastic counterparts, which include the lack of connection with the shallow bank top, the small size of the sedimentary system, and the lack of sandy turbidites (Betzler et al., 2014; Mulder et al., 2012, 2014; Wunsch et al., 2017).

A complete understanding of the production, preservation, and accumulation of neritic carbonates at the scale of a carbonate platform thus necessitates investigating the entire depositional system, by integrating production, transfer, and storage of neritic $\mathrm{CaCO}_{3}$ along the sediment routing system. Our study presents an example of a modern carbonate source-tosink system, by investigating the platform top and the adjacent slope and basin of Glorieuses, an isolated carbonate platform located in the SW Indian Ocean. The study of the entire system allows us to attempt to make a first quantification of sediment volume produced during the present-day highstand and presently stored on the platform top, and to estimate the volume exported toward the deep sea since the last reflooding (i.e. Holocene) of the platform. Links with platform top production and sediment export and trigger mechanisms are also discussed at the scale of the glacial/interglacial high-amplitude sea-level fluctuations of the Late Quaternary. 


\section{Study area}

Located in the volcanic axis of the Comoros, the Glorieuses archipelago developed at the top of a seamount in the northern part of the Mozambique Channel, North of Madagascar and North-East Mayotte (Figure 1A). The volcanic edifices of this region are interpreted as resulting from the activity of a hot spot under the Somali plate (Emerick and Duncan, 1982). An alternative hypothesis considers that the islands may be the product of the injection of basaltic magma along old lithospheric fractures trending NW-SE related to the drift of Madagascar relative to Africa (Nougier et al., 1986).

The base of the Glorieuses seamount is composed of encrusted trachy-andesite to trachyte lavas (Courgeon et al., 2016). The flanks of the Glorieuses platform and the nearby areas contain several flat-topped terraces and associated slope breaks ranging from $1100 \mathrm{~m}$ to $35 \mathrm{~m}$ water depths, interpreted as drowned carbonate platforms, the oldest one being Paleocene in age (Courgeon et al., 2016). The shallowest reef terraces located between $120 \mathrm{~m}$ to $35 \mathrm{~m}$ of water depth have been interpreted as reflecting brief periods of extremely rapid sea-level rise during the last deglaciation (Jorry et al., 2016) initiated 20,000 years ago (Blanchon and Shaw, 1995; Clark et al., 2004; Deschamps et al., 2012; Hanebuth et al., 2000; Weaver et al., 2003).

The climate of this region is tropical and characterized by two distinct seasons. The cool season, from May to November (Austral winter), is dominated by SE trade winds and daily average temperatures ranging from 24.8 to $27.7{ }^{\circ} \mathrm{C}$. The hot season, from December to April (Austral summer), is influenced by the NW monsoon; daily temperatures average $28{ }^{\circ} \mathrm{C}$ and the humidity ranges from 81 to $84 \%$. At Glorieuses, the dominant trade winds blow from the 
east during March and December, and monsoon winds come from southwest to northwest during January and February (Figure 1C). Rainfall is about 110 to $210 \mathrm{~mm}$ per month, with a maximum in January. The Glorieuses Islands are directly affected by the Northeast Madagascar Current (NEMC), flowing westwards off north Madagascar. The NEMC transports about $30 \mathrm{~Sv}$ and supplies water for the Mozambique Channel flow and the East African Coastal Current (Schott et al., 2009; Swallow et al., 1988). The NEMC has a weak seasonal variability (Schott et al., 2009; Schott and McCreary, 2001). (Swallow et al., 1988) estimated a seasonal variation in the transport of about $2 \mathrm{~Sv}$ at $10-12^{\circ} \mathrm{N}$, presenting the highest values in August/September and the lowest in January/February.

\section{Materials and methods}

Data were collected during a set of scientific expeditions between 2011 and 2015 in Glorieuses. Data from shallow areas (up to $200 \mathrm{~m}$ water depth) were acquired in the frame of the REEFCORES (REEFs and CORals from the EparseS) program, during three cruises completed in 2011 onboard the RV Marion Dufresne, and in 2013 and 2015 onboard the Antsiva schooner. Data concerning the slope and basin adjacent to the Glorieuses platform were acquired onboard the R/V L'Atalante during the 2014 PTOLEMEE (Jorry, 2014) and PAMELA-MOZ1 (Olu, 2014) expeditions, as part of the PAMELA project (PAssive Margins Exploration LAboratory).

\subsection{Oceanographic measurements}

Maximal daily velocity of the wind at $10 \mathrm{~m}$ above the ground were registered on the Météofrance station in the Glorieuses Island (station number 98403001, 47¹7'18' $\mathrm{E}$ 
$11^{\circ} 34^{\prime} 54^{\prime}$ 'S) from January 2007 to November 2013. Wind speed and direction at sea was obtained from the meteorological station onboard the $R / V L$ 'Atalante during the PTOLEMEE survey in 2014. At the same time, current velocity data were obtained from a hull-mounted ADCP $(150 \mathrm{kHz})$. The ADCP data were processed using the Cascade 7.1 software (Ifremer in-house software).

\subsection{Bathymetry and backscatter sonar images}

A bathymetric survey was performed in 2015 along the Glorieuses platform edge, in water depths varying from 5 to $200 \mathrm{~m}$. We operated a Kongsberg EM3002 multibeam echo sounder (293 or 300 or $307 \mathrm{kHz}, 160$ beams, emission and reception angles of $0.5^{\circ}$ and $1^{\circ}, 50$ to $400 \mathrm{~ms}$ pulse length) onboard the Antsiva schooner.

Multibeam surveys were conducted onboard the $R V$ L'Atalante to systematically map slope and basins adjacent to the Glorieuses archipelago. The deeper seafloor data (> $1000 \mathrm{~m})$ were acquired with a Kongsberg EM122 multibeam echo sounder $(12 \mathrm{kHz}, 288$ beams, emission and reception angles of $1^{\circ}$ and $2^{\circ}, 2$ or 5 or $15 \mathrm{~ms}$ pulse length), with automatic swath width control and an equidistant sounding pattern over water depths varying from 1500 to $5000 \mathrm{~m}$. The shallower seafloor data (100-1000m) were acquired with a Kongsberg EM710 multibeam echo sounder (70 to $110 \mathrm{kHz}, 256$ beams, emission and reception angles of $1.5^{\circ}, 0.15$ to $2 \mathrm{~ms}$ pulse length), with manual swath width control over water depths varying from 200 to $1500 \mathrm{~m}$.

Furthermore, laser bathymetry and topography (LiDAR) were available throughout the archipelago (Litto3D® database). The LiDAR acquisition was published in 2012 
(https://diffusion.shom.fr/pro/risques/altimetrie-littorale/litto3d-eparses2012.html) by the

French Institut Geographique National (IGN) and Service Hydrographique et Oceanographique de la Marine (SHOM). Bathymetric and topographic LiDAR allowed metric accuracy on the plane and decimetric precision of heights and depths.

\subsection{Seismic acquisition}

A sparker Source, a single-channel SIG streamer and a numerical DELPH acquisition system were used to acquire about $250 \mathrm{~km}$ of high-resolution seismic profiles in shallow waters ( $<200 \mathrm{~m}$ water depth). The sparker emission energy ranged from 25 to $160 \mathrm{~J}$, the shooting rate was $250 \mathrm{~ms}$ and the vessel bottom speed was 4 to 5 knots. Raw data were processed using Delph Interpretation (developed by iXBlue). Interpretation of seismic lines was conducted using Kingdom Suite software (IHS Markit). Seismic lines are displayed with two-way travel time in ms. Time-depth conversions have been made assuming an average velocity of 1800 $\mathrm{m} / \mathrm{s}$ for unconsolidated sediments (Kenter et al., 2002). The signal penetration is satisfactory in lagoonal sediments, although the attenuation of the high-resolution signal is significant beneath the high amplitude reflectors that correspond to reefal substrates, and amplifies the seabed multiple reflector in shallow water. These limitations prevent the examination of inner reefal structures and the lower part of seismic records.

Seismic lines along slope and basin (areas deeper than $200 \mathrm{~m}$ ) were collected using the seismic acquisition system SEAL (Sercel, Ifremer). Multichannel seismic data were acquired at 10 knots using a short $(600 \mathrm{~m})$ streamer (24 traces of 12.5 mgroup length each) without any active depth controller or buoy, and two sub-arrays of a single GI air gun each which were 
towed at $6 \mathrm{~m}$ depth using tow fishes. Fast seismic processing consisted of a basic trace stacking and migration at constant velocity $(1500 \mathrm{~m} / \mathrm{s})$.

\subsection{Sediment cores}

Four sediment cores (RC-GLO-C024/C025/C029/C030) were collected on top of the Glorieuses platform in intertidal zones (see locations on Figures 1 and 3), using a 1-m-long hand corer. Physical properties (which includes the gamma density) and X-Ray images were measured by using a Multi-Sensor Core Logger and a X-CT Scan, respectively, both manufactured by Geotek. Two piston cores (MOZ1-KS04 and MOZ1-KS07) were collected in the Glorieuses basin using a Kullenberg corer system (see location on Figure 1). Physical properties and X-ray computed tomography were acquired following the same process as for the platform cores. The sedimentological description of all cores was conducted during the postcruise sampling, and main types of sediments and sedimentary structures were differentiated.

The stratigraphy of the two basin cores was established using oxygen isotopes measured on batches of several specimens of Globigerinoides ruber. Samples were collected in layers composed of pelagic periplatform carbonate, purposely excluding turbidites. On average, 10 to 15 specimens were picked from the 250 - $315 \mu \mathrm{m}$ fraction. Analyses were performed with a Thermo MAT253 Mass Spectrometer, operated by the Pôle Spectrométrie Océan (PSO) at the Institut Universitaire Européen de la Mer (IUEM / UBO), Plouzané, France. Isotopic data are reported in the conventional $\delta$ notation relative to VSMOW for $\delta^{18} \mathrm{O}$. The repetition of 10 measurements of a calcite working standard gave a precision $(1 \sigma)$ of $0.05 \%$ for $\delta^{18} \mathrm{O}$. 
Nine radiocarbon dates were also obtained from the upper sections of the deep basin cores.

For each AMS dating, approximately 500 specimens of G. ruber were picked from the $>250$ $\mu \mathrm{m}$ fraction, washed with distilled water in an ultrasonic bath, and dried and analyzed by Beta Analytic Limited. Radiocarbon ages (Table 1) have been converted to calendar dates with the program OxCal 4.2, using a P_Sequence depositional model (Ramsey, 2008, 2009), the IntCal13 calibration curve (Reimer et al., 2013), and a surface water reservoir age of $500 \pm$ $130 \mathrm{y}$ (Key et al., 2004). For the sections of the core beyond the range of radiocarbon dating, the chronology was based on correlation of $\delta^{18} \mathrm{O}$ with reference records. Core MOZ1-KS04 benthic (Cibicides wuellerstorfi) $\delta^{1} 8 \mathrm{O}$ record was correlated to the LR04 benthic stack (Lisiecki and Raymo, 2005) using the program AnalySeries (Paillard et al., 1996). Core MOZ1-KS07 lacks a benthic isotopic record, so its G. $r u b e r \delta^{18} \mathrm{O}$ record was correlated to the planktonic $\delta^{18} \mathrm{O}$ of nearby record MOZ4-CS09 (Counts et al., 2019), itself with a primary age model based on correlation of its benthic $\delta^{18} \mathrm{O}$ record to the LR04 benthic stack.

Variation in Strontium ( $\mathrm{Sr}$ ) content was measured by a X-Ray fluorescence core scanner (XRF-CS). The Sr XRF-CS profile was quantified using Wavelength Dispersive X-ray Fluorescence (WD-XRF) measurements of sediments collected along core MOZ1-KS04, and the aragonite percentage was determined by X-ray diffraction (XRD). Aragonite fluxes were calculated in order to estimate the contribution of platform top-derived fine sediments in the deep adjacent basin. The aragonite fluxes (AF; $\mathrm{g} . \mathrm{cm}^{-2} \cdot \mathrm{kyr}^{-1}$ ) at site MOZ1-KSO4 were quantified according to the following formula: AF = LSR x DBD x (\% aragonite), with LSR: Linear Sedimentation Rate (cm.kyr $\left.{ }^{-1}\right)$ and DBD: Dry Bulk Density $\left(\right.$ g. $\left.\mathrm{cm}^{-3}\right)$.

\subsection{Estimating platform top sedimentary facies distribution}


The distribution of sedimentary facies on the platform top was mapped using a combination of the satellite images and direct observations of bottom type and biota (including 138 sediment samples collected with a box corer), as previously documented in detail by Prat et al. (2016).

\subsection{Estimating Recent and Holocene carbonate production}

In order to estimate the total volume and mass of $\mathrm{CaCO}_{3}$ produced on the Glorieuses platform through the Holocene, we combined the volume of sediment preserved in the Holocene sand bodies on the platform with the volume of sediment represented in the submarine fans draining the leeward side of the platform to the northwest. The area and volume of the carbonate sand bodies on the platform top were estimated using the $2 \mathrm{D}$ shallow seismic profiles. Sufficient profiles along and across the sand bodies were collected to estimate the volume of the sandy isopach (Figure 3B). The area of the submarine fans in the Glorieuses deep-sea basin was estimated from multibeam bathymetry, backscatter and seismic profiling. The thickness of Holocene sands and muds was based on the average thickness of sand and mud facies within the two cores, which has accumulated since the earliest Holocene (radiocarbon dates of 10,8 ka cal BP in MOZ1-KS04, 10,5 ka cal BP in MOZ1-KS07; Table $1)$.

In order to compare the volume of sediment produced on the Glorieuses platform with regional and global carbonate production estimates, we converted volumes to mass via the

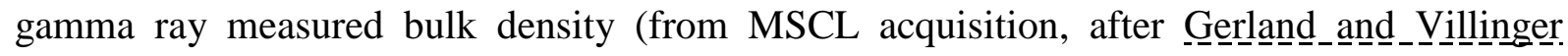
(199252) of sand and mud facies within sediment cores. We used the four gravity cores collected covering the sand bodies atop the Glorieuses platform to estimate the density of the 
platform-top sand bodies. Gamma ray density measurements of these four cores were used to convert the volume of carbonate sand in these sand bodies into a total mass of $\mathrm{CaCO}_{3}$. Bulk density of sandy calciturbidites and muddy intervals within the two deep basin cores were measured separately.

\section{Results}

\subsection{Oceanography}

Hull mounted ADCP data acquired in September 2014 (during the period of highest transport according to Swallow et al., 1988) show mainly a NW-W direction of the surface currents (at 60-150 m water depth). Current velocity is very high, reaching up to $150 \mathrm{~m} \cdot \mathrm{s}^{-1}$ at the north of the island and $80-90 \mathrm{~cm} \cdot \mathrm{s}^{-1}$ at the northern and southern flanks of the island (Figure 2A). These values are in agreement with the measured and simulated magnitude of the NEMC of around $100 \mathrm{~cm} \cdot \mathrm{s}^{-1}$ (Jose et al., 2016; Schott and McCreary, 2001). In contrast, currents are slower at the western flank of the island ranging between 20 and $40 \mathrm{~m} \cdot \mathrm{s}^{-1}$ (Figure 2A). Wind data acquired onboard at the same time show that the winds around the Glorieuses Island present mainly an easterly component (Figure 2B), in concordance with the measurements from the station on the island (Figure 1C). In the Glorieuses Island the dominant wind is from the east, although there are some periods of opposing wind (from SW, W and NW), especially during the rainy season (December to April) (Figure 1C). The wind and current directions are coherent with the sediment plume extending from the western part of the island observed from a satellite image (Figure 2C). The strong east winds may favour the export of fine sediment through the western part of the island. Moreover, currents in the same direction may 
also transport the sediment westwards; sediment would be concentrated along the west side of the island, where the currents are the lowest (Figure 2A).

\subsection{Sediment distribution on Glorieuses platform top}

The Glorieuses platform exhibits several facies belts including islands, the reef flat, the reef front, the apron, a shallow and a deep inner platform (up to $15 \mathrm{~m}$ water depth), and the forereef (Table 2, Figure 3). Sediments on platform top, dominated by Halimeda fragments (Jorry et al., 2016), are mainly derived from typical tropical carbonate producers such as corals, large benthic foraminifers, Halimeda, and molluscs. The distribution of all these fragments is controlled mainly by the location of carbonate producers on the archipelago, by local hydrodynamics (tide and waves) and exceptional events such as storms and cyclones which induce the reworking of sediments and the winnowing of mud (Prat et al., 2016). These sediments accumulate on three main localities: the back reef (including the sand apron), the leeward platform edge, and at the northeastern edge of the platform where carbonate sands are deposited on top of successive submarine terraces (Figure 3). The development and lateral migration of the sand dunes on the platform (about $43 \mathrm{~m} / \mathrm{year}$ toward the southwest) reveal the importance of the activity of shallow currents (waves and/or tide) on the inner platform, despite the shelter induced by the presence of the barrier reef (Prat et al., 2016).

Two main seismic sequences can be identified on seismic profiles: a lower sequence characterized by chaotic seismic facies interpreted as an old reef substrate, and an upper sequence showing stratified seismic facies, interpreted as uncemented sands deposited since the last reflooding of the platform top and mostly during the Holocene (Figure 4). 
Sand dunes form a large sand apron beside the reef flat. The sand dunes are sub-parallel bodies, $1.5 \mathrm{~m}$ high on average and are oriented SW-NE. They are less than $100 \mathrm{~m}$ wide, and their length ranges from 500 to $600 \mathrm{~m}$; the top of the sand dunes is on average 0.2 to $1 \mathrm{~m}$ deep at low tide. The general morphology of sand dunes is characterized by a gentle southeast (seaward) flank and a steeper face to the northwest (bankward). This morphology is seemingly influenced by E-W currents, whereas the intertidal and deeper sand dunes on the inner platform are probably shaped by NW-SE currents. The migration of intertidal sand dunes has been estimated at about $43 \mathrm{~m} /$ year, with a significant migration observed towards the south/southwest, increasing in the same direction over several years (2004 to 2009, after Prat et al., 2016). Based on seismic profiles, the overall sediment accumulation on the back reef is approximately $15 \mathrm{~m}$ thick, few hundreds of meters off the sand apron. It shows some progradation toward the platform interior with a decreasing thickness, before completely disappearing $8 \mathrm{~km}$ from the reef flat (Figure 4A and Figure 4B).

Sediments that have accumulated along the leeward edge of the platform form large subaqueous dunes, in 40 - $60 \mathrm{~m}$ water depth (Figure 1E). These dunes are elongated (5 to 16 $\mathrm{km}$-long) sand bodies about 5 to $20 \mathrm{~m}$-thick, showing some plurimetric prograding sets separated by erosional surfaces (Figures 4C and 4D). They are lying on a seismic unit characterized by chaotic seismic reflections and incisions. This unit is interpreted as an old reef sequence, whose irregular top probably results from erosion during past sea level lowstands. Three radiocarbon dates have been performed on monospecific assemblage of large benthic foraminifera (Amphistegina lessonii) which have been picked in sediments collected on top of these bodies with a sediment dredge (sample RC-GLO-B248, Table 1, location on Figure 3A). These samples give ages ranging from 0,8 to $0,9 \mathrm{ka}$ cal $\mathrm{BP}$, attesting that the feeding of these bodies was active during the late Holocene. Taking into account 
observations on the displacement of sand dunes at present-day (Prat et al., 2016), we assume that the deposition of carbonate sands along the leeward platform edge is probably still active at present.

The deposition of carbonate sands is also observed on top of submerged terraces located at the north-eastern edge of the Glorieuses platform, those terraces having been interpreted as the imprint of the last deglacial sea-level rise (Jorry et al., 2016). Sands preferentially accumulated on the largest (4 to $5 \mathrm{~km}$-wide) terrace located at $35 \mathrm{~m}$ water depth, forming an 8 m-thick horizontally stratified sand sheet (Figure 4E and 4F).

Based on the seismic interpretation and geomorphological observations, the volume of sediments that accumulated on the Glorieuses platform top (which represents a surface of about $188 \mathrm{~km}^{2}$, with $80 \%$ of the area ranging between 0 and $20 \mathrm{~m}$ of water depth) has been estimated at about $0.3 \mathrm{~km}^{3}$ (Table 3). A significant amount of sands is preferentially accumulated and stored along the leeward platform edge, forming thick elongated carbonate sand dunes. Taking into account that the main carbonate productivity occurs in the inner platform and the reef flat, we interpret these dunes as the result of transportation of sediment mainly from the back-reef apron, where sand dunes migrate towards the south/southwest with a possible outlet located at the northwest of main island, i.e. Grande Glorieuse (Prat et al., 2016). The storage of carbonate sands along the leeward platform edge is also in agreement with reduced current and wind effects measured at this location (Figure 2).

\subsection{Sediment accumulation along the Glorieuses slope and adjacent basin}


Bathymetry acquired offshore the Glorieuses archipelago revealed the presence of a steep slope (about $45^{\circ}$ ) with lineaments, probably volcanic in origin (Figure 1B). Some incisions are observed, but these do not connect to the platform top, originating instead from the smooth, steeper upper platform slope. The floor of these channelized features is generally flat, lacking a thalweg, and seem to collect platform-derived sediments delivered to the upper slope / platform edge transition (Figure 1D). The increased backscatter seen in these channels indicates that sediment within channel margins is probably coarser-grained than that surrounding it. The basin, in approximately $3700 \mathrm{~m}$ water depth, shows some lobe-shaped sedimentary accumulations and channels imprinted on the sea floor, at the base of the leeward-platform slope (Counts et al., 2018) (Figure 1B). All these accumulations are typified by a basin extent of 35 to $50 \mathrm{~km}$ maximum. Sediments accumulated in the deep basin are characterized by the stacking of thick (up to $450 \mathrm{~ms}$ TWT, i.e $\sim 250 \mathrm{~m}$-thick) bodies, which together rest on a volcanic substrate (Counts et al., 2018) (Figure 5). The upper $200 \mathrm{~ms}$ show some seismic units composed of amalgamated erosive features, interpreted as channel-levee systems and turbiditic fans, and chaotically bedded debris flows (Counts et al., 2018). Based on seismic data, Counts et al. (2018) also interpreted some of these uppermost sedimentary deposits as depositional thrusts resulting from downslope mass movement of slope sediments. Undulating surface features seen on the proximal basin floor may be the surface expression of these thrusts, but may also be sediment waves.

Two sediment cores were collected in the deep basin adjacent to the Glorieuses platform. MOZ1-KS04 was collected in $3167 \mathrm{~m}$ water depth along a channel levee system, and core MOZ1-KS07 was retrieved from $3751 \mathrm{~m}$ water depth on a distal lobe (Figure 1B). Analysis and description of both sediment cores show bundled calciturbidites and carbonate mud (Figures 6A and 6B). The calciturbidites form centimetre to decimetre well-laminated and 
normally graded beds, with erosive bases (Figure 6C and Figure 6D). They represent $7.6 \%$ $(85 \mathrm{~cm})$ and 19,8\% $(148 \mathrm{~cm})$ of the total sediment composition, in core MOZ1-KS07 and core MOZ1-KS04, respectively, the remaining content being composed of carbonate mud (containing 25\% aragonite on average). While calciturbidites appear more abundant in core MOZ1-KS04 than in core MOZ1-KS07, we noted that the composition of the calciturbidites of both sediment cores is very similar to coarse-grained carbonate sands collected on the platform tops, including coral, Halimeda and mollusc fragments, as well as well-preserved large benthic foraminifera tests (Figures 6E and 6F) including Sorites, Amphisorus, Neorotalia, Cibicides, Calcarina, among others.

We also noted that the Sr signal is different between the two sediment cores (Figures 6A and 6B), with Sr concentrations much higher in the proximal core MOZ1-KS04 than in the distal core MOZ1-KS07. Sr peaks are correlated with the presence of calciturbidites in both cores, while some progressive downcore enrichment in the Sr content observed also in hemipelagic layers in core MOZ1-KS04, between 0 and $450 \mathrm{~cm}$ core depth. By measuring the aragonite percentage and the $\mathrm{Sr}$ abundances along core MOZ1-KS04, it can be demonstrated that $\mathrm{Sr}$ variations (at least in hemipelagic sediments) are mainly driven by the aragonite composition of sediments (which ranges between 3\% and 44\%) (Figure 7). Therefore, we can consider the $\mathrm{XRF} \mathrm{Sr}$ variation as a proxy to estimate the relative concentration in aragonite of basin sediments.

According to the extent of lobes and channel-levee complexes that can be seen in the basin adjacent to the leeward-platform slope (Figure 1B), the depositional area in the deep basin approximates $600 \mathrm{~km}^{2}$ in Glorieuses (Table 3). It is bounded at its northeastern extremity by a volcanic ridge about $1 \mathrm{~km}$ high, which may act as a topographic barrier for gravity flows 
coming from the platform top, and contributes also to avoid the reworking of sediments by potential deep contour currents (consistent with the absence of contourites on seismic lines).

4.4. Estimate of the carbonate routing system since the last reflooding of the Glorieuses platform

Age models have been established on the two sediment cores using $\delta^{18} \mathrm{O}$ isotope stratigraphy. Core MOZ1-KS04 displays a 206 kyr record and MOZ1-KS07 core goes back to $386 \mathrm{ka}$ (see Figure 10). For the two cores, fluctuations of the $\delta^{18} \mathrm{O}$ are in agreement with the wellestablished global sea-level changes. Based on the nature of the deposits observed at the two core sites in the basin, two main processes at the origin of sediment transfer from the platform top toward the basin can be invoked: neritic carbonate sands that were transferred downslope by gravity currents, and aragonitic mud was winnowed from the platform under the action of currents and dominant wind and deposited by settling through the water column (c.f. oㅡ므므. et al.._2019; Wilson and Roberts, 19995). Considering that the mean depth of the modern Glorieuses platform edge is located at $-60 \mathrm{~m}$ (value based on geomorphological settings of the Glorieuses platform edge which is bordered by last deglacial submerged terraces ranging from $35 \mathrm{~m}$ to $90 \mathrm{~m}$ water depth, as published in Jorry et al. (2016)), we tried to estimate the carbonate budget of the entire platform/basin system since the latest deglacial sea level rise (i.e. Holocene), when the Glorieuses platform was entirely flooded and started to produce carbonate sediments (Table 3).

The average bulk density of the sand and mud facies within the deep basin cores is 1.590 $\mathrm{g} / \mathrm{cm}^{3}$. The two cores have considerable differences in density properties, with proximal core MOZ1-KS04 displaying much larger variation in density, and much higher density of sand 
layers than in mud layers, particularly in the lower $1 / 3$ of the core (Figure $8 \mathrm{~A}$ ). In order to estimate the density of sediments exported since the Holocene transgression, we measured the bulk density of sandy and muddy facies within each core from the Last Glacial Maximum to the present (18.6 ka in core MOZ1-KS04; $19.1 \mathrm{ka}$ in core MOZ1-KS07); the age range was extended to LGM for both cores to ensure that both sandy and muddy facies since the Holocene transgression were represented, and because linear sediment accumulation curves cannot be assumed based upon the core age model. The average density of post-LGM sand bodies was $1.640 \pm 0.086 \mathrm{~g} / \mathrm{cm}^{3}$, while the average density of muds was $1.655 \pm 0.045 \mathrm{~g} / \mathrm{cm}^{3}$. Surprisingly, the bulk density of muds in the proximal core, MOZ1-KS04, was higher than for the distal core $\left(1.851 \pm 0.047 \mathrm{~g} / \mathrm{cm}^{3}, 1.501 \pm 0.018 \mathrm{~g} / \mathrm{cm}^{3}\right.$, respectively). This difference may be attributable to a larger grain size in the proximal core, in which muds are dominantly silty in its upper $1 \mathrm{~m}$, as opposed to dominantly clay muds in the distal core.

The sediment cores show that on average $23 \mathrm{~cm}$ of neritic carbonate sands have been exported from the platform top since its last reflooding, i.e. $25 \%$ of the total sediment deposited in the deep basin during the Holocene (Table 3). To estimate the portion of carbonate muds derived from the local platform, we used the $\%$ aragonite values within the muddy portions of the deep basin cores, noting that most tropical pelagic carbonates in the region are calcitic (e.g. coccolithophores, planktonic foraminifera), while carbonate muds derived from the platform are almost exclusively aragonitic, being composed primarily of fine debris of Scleractinian corals, Halimeda, and gastropod shells (Counts et al., 2019; Jorry et al., 2016). Calciturbidite lobes and channels cover an area of about $600 \mathrm{~km}^{2}$; we estimate that about $0.55 \mathrm{~km}^{3}$ of carbonate sediments have been deposited in the basin during the last $10 \mathrm{kyr}$, including 0.14 $\mathrm{km}^{3}$ of neritic sands transferred by gravity currents and $0.13 \mathrm{~km}^{3}$ of aragonitic muds, the latter being winnowed from the platform top and settled down through the water column (Table 3). 
Our data from sediment cores suggest that the aragonite represents $32 \%$ of the fine sediments deposited during the last $10 \mathrm{kyr}$ (Table 3), with aragonite percentage decreasing offshore with water depth (from proximal (i.e. core MOZ1-KS04) to distal (i.e. core MOZ1-KS07), aragonite content ranges respectively from $30 \%$ on average to few \%).

To explain the preservation of well-laminated calciturbidite beds (Figures 6C and 6D), we show that gravity currents might have also incorporated some mud, which would favour the occurrence of wavy and planar laminations (Figures 6C and 6D). We also suggest that turbidity currents originating from carbonate slopes might have a low transport capacity compared to siliciclastic counterparts, explaining the relatively short distance of propagation on the Glorieuses abyssal plain (less than $50 \mathrm{~km}$ ).

Based on these estimates, we calculated that the average carbonate production of the Glorieuses platform since the last reflooding (i.e. Holocene) can be estimated at about 0.57 $\mathrm{km}^{3}$. This volume includes $0.3 \mathrm{~km}^{3}$ of neritic sands which at present still are stored on the platform top, and $0.27 \mathrm{~km}^{3}$ of carbonate sand and mud exported to the basin. The estimated volume of carbonate muds exported from the platform is a minimum estimate, based on the area of deposition within the sediment lobes and fans mapped along the leeward side. Carbonate mud winnowed from the platform and exported in other directions has not been estimated. Thus we may infer that at least half of the sediments produced on the Glorieuses platform during the last $10 \mathrm{kyr}$ have been reworked and transported onto the slopes or into the proximal basin (Figure 9).

\subsection{Comparison with regional and global carbonate production estimates}


The validity of these carbonate production estimates was tested by comparing them with various global and regional production estimates produced by a variety of methods. Three global tropical reef carbonate production estimates (Kleypas, 1997; Milliman, 1993; Vecsei, 2004) were applied to the Glorieuses example by calculating the average annual production rate per $\mathrm{km}^{2}$, and applying this to the marine area of the Glorieuses platform $\left(183 \mathrm{~km}^{2}\right.$, Table 4). In addition, three regional production estimates from the Torres Straits (Leon \& Woodroffe 2013) the central Great Barrier reef (Hamylton et al., 2017), and the Indian Ocean (Perry et al., 2015) were considered, and the percentage of estimated production was calculated relative to the global estimate (Table 4). For the Torres Strait example, which represents a mesotidal to macrotidal environment similar to Glorieuses, only the crescentic reefs were considered, as this was the reef morphology most similar in shape to the Glorieuses platform. Average Holocene annual carbonate production estimates for the Glorieuses archipelago $\left(9.26 \cdot 10^{8} \mathrm{~mol} / 9.27 \cdot 10^{7} \mathrm{~kg}\right)$ were $14-34 \%$ of the carbonate production estimated from regional or global average carbonate per $\mathrm{km}^{2}$ production rates.

\section{Discussion}

\subsection{Lessons from past interglacials in the Glorieuses basin}

Both sediment cores offer the opportunity to evaluate the timing and the distribution of calciturbidites in the Glorieuses basin over the last $200 \mathrm{ky}$, from proximal to distal location. By comparing the two records, the number of turbidites deposited in the Glorieuses basin appears to be higher during interglacial periods, in particular when sea level rose above $-60 \mathrm{~m}$ of water depth, which corresponds to the mean depth of the present-day Glorieuses platform edge (Figure 10). During these periods, the deposition of turbidites seems to be preferentially 
preserved in the proximal basin (i.e. location of core MOZ1-KS04, where $148 \mathrm{~cm}$ of carbonate sands have been accumulated). The thickest accumulation $(101 \mathrm{~cm})$ of interglacial turbidites occurred during MIS7 on both cores (Figures 10D and 10E). In addition, the increase of aragonite flux observed at core MOZ1-KS04 (Figure 10A) when sea level rose above $-60 \mathrm{~m}$ is consistent with the highstand shedding model. According to this model, when the platform is flooded, excess sediment produced on the platform top is exported to the adjacent deep sea (e.g. Counts et al., 2019; Droxler and Schlager, 1985; Glaser and Droxler, 1993; Jorry et al., 2010; Schlager et al., 1994).

The difference in turbidite frequency in each core indicates that individual turbidite events do not result in deposits that cover the entire proximal basin floor on the north western side of the platform. However, except for MIS7, flooding of the Glorieuses platform at the beginning of each interglacial, was apparently marked by systematic and sudden increases of aragonite fluxes on core MOZ1-KS04 (Figure 10A). Increased aragonite flux appears decisive for calciturbidite deposition in the adjacent basin, as reported for several examples described in other carbonate basins (Andresen et al., 2003; Webster et al., 2012). For MIS7, there has been considerable ambiguity regarding the relative heights of the three highstands, namely MIS7a, MIS7c and MIS7e. Sea levels estimated from reconstructions based on benthic oxygen isotope $\left(\delta^{18} \mathrm{O}\right)$ data (Bintanja et al., 2005; Lisiecki and Raymo, 2005; Waelbroeck et al., 2002) predict similar peak sea level at, near, or just below that of the present day, whereas other sealevel curves based on other proxies (speleothems) indicate a lower elevation for MIS 7c, near -18m (Dutton et al., 2009). Our data show that turbidite deposition thickness and aragonitic fluxes were much higher during MIS7 than for any other interglacials in the Glorieuses basin (Figure 10D and Figure 10E). This could be explained by a sea level which persisted at a level between 0 and $-60 \mathrm{~m}$ for a long time (Bintanja et al., 2005; Dutton et al., 2009; Lea et al., 
2002; Thompson and Goldstein, 2005; Waelbroeck et al., 2002). Interestingly, this bathymetric range coincides precisely at Glorieuses with the platform surface able to store sediments (including platform top and submerged terraces). The relatively low number of calciturbidites during the last interglacial (MIS 5e) is also noted on both cores. Although it might be realistic to consider that turbidites has been produced during MIS5e and exported elsewhere in the deep basin (in a region not sampled by our sediment cores), another alternative hypothesis can be proposed. Considering that sea level rose at +5 to $+8 \mathrm{~m}$ above modern sea level during MIS5e (Dutton and Lambeck, 2012; Lambeck and Chappell, 2001), the Glorieuses platform was totally submerged, increasing the potential area for sediment storage by $15 \%\left( \pm 46 \mathrm{~km}^{2}\right)$ due to the drowning of the modern reef flat and exposed islands.

The relatively high number of calciturbidites deposited during MIS6 at both sites suggests that reworking processes along the carbonate slope might have occurred during lower sea levels (corresponding to periods when sea level was stagnated between 60 and $100 \mathrm{~m}$ water depth). This interpretation is reinforced by the presence of sediments that presently drape the upperslope of Glorieuses during the modern highstand (Figures 1D and 3). All these observations demonstrate that the topography of carbonate platform edges and leeward slopes is playing an important role by storing sediment that might be initially shed during highstands, which is then re-mobilized during lowstands and deposited as calciturbidites.

Because hemipelagic sediments of core MOZ1-KS07 exhibit relative low Sr concentrations, we infer that the flushing of aragonitic mud from the platform top was limited in how far it could travel offshore in suspension to about $30 \mathrm{~km}$ maximum, as observed in the present day (Figure 2C). Another explanation for the low Sr counts in MOZ4-KS07 may be related to the greater depth of this core (3751 m water depth) compared to MOZ1-KS04 (3167 m water 
depth), as the dissolution of aragonite might occur more readily at greater depths. At the present time the carbonate compensation depth (CCD) in the Indian Ocean occurs at approximately 5000 meters of water depth, assuming that the Somali Basin is a typical equatorial area with no significant dilutions by terrigenous debris (Kolla et al., 1976). Because aragonite is more soluble than calcite, its compensation depth is generally considered to be shallower than for calcite. In the Mozambique Channel, some aragonite dissolution has been previously documented in the basin adjacent to Juan de Nova island (at about $1900 \mathrm{~m}$ water depth), in the form of pitting on the surface of aragonite needles (Counts et al., 2019).

\subsection{Implications for modern and ancient counterparts}

Carbonate production by coral reefs located throughout the tropical and sub-tropical oceans is an important component of the global carbon cycle (Vecsei, 2004). Global estimates are dependent on up-scaling from a small number of individual coral reef studies that represent limited coverage of the world's reefs. At the reef platform scale, carbonate production estimates are also of critical importance in understanding the geological and geomorphic development of coral reefs and islands. Furthermore, carbonate production by primary frame builders and secondary benthic organisms, along with mechanical and biological erosion, control the generation of detrital sediment on reef platforms, sediment which is subsequently follows one or more pathways: reincorporation into reef framework (Hubbard et al., 1990), storage on reef surfaces, off-reef transport (Hughes, 1999; Jorry et al., 2008, 2010; Mullins et al., 1984; Puga-Bernabéu et al., 2014), transfer to infill lagoons (Kench, 1998; Macintyre et al., 1987; Purdy and Gischler, 2005) or transfer landward to build islands (Hopley, 1982; Maragos et al., 1973; Woodroffe and Grime, 1999; Yamano et al., 2002, 2000). For the Glorieuses, the carbonate productivity initiated by reef corals, Halimeda, benthic 
foraminifera, and other reef-dwelling benthic organisms, contributes actively to the general evolution of the platform, at least since the last reflooding. Detrital carbonate sediments are mainly stored on the platform top and along the leeward edge, and exported downslope. The production estimates discussed in this study can be compared to previous carbonate production estimates on coral reefs and carbonate platforms (Table 4). The annual $\mathrm{CaCO}_{3}$ carbonate production of the Glorieuses platform approximates $9.27 \cdot 10^{8} \mathrm{~mol} . \mathrm{km}^{-2}$. Compared with the global $\mathrm{CaCO}_{3}$ production of coral reefs in the world oceans (i.e. $9 \cdot 10^{12}$ mol.yr $^{-1}$ for an area of about $6 \cdot 10^{5} \mathrm{~km}^{2}$ (Milliman, 1993), i.e. $27.5 \cdot 10^{8}$ mol.yr $\mathrm{yr}^{-1}$ for a carbonate platform of about $188 \mathrm{~km}^{2}$ ), the estimated carbonate production rates at Glorieuses are of comparable order of magnitude, but somewhat lower than predicted (Table 4).

The Glorieuses carbonate platform appears to produce carbonate sediments at 25-60\% of most regional and global carbonate production rate estimates. The net carbonate production rate for the Chagos archipelago (pre-bleaching; Perry et al. 2018) refers strictly to the coral reefs of Chagos, and does not consider the associated non-reefal carbonate facies, hence is not completely representative of Glorieuses, even though situated close. The gross production rate from crescentic reefs in the Torres Strait is the weighted average of 36 crescentic reefs ranging in size from 0.9 to $194 \mathrm{~km}^{2}$ (average $26.7 \mathrm{~km}^{2}$ ), and with gross production rates ranging from $0.5-10 \mathrm{~kg} / \mathrm{m}^{2} / \mathrm{y}$ (Leon and Woodroffe 2013), emphasizing the tremendous range of variability in carbonate production within reef or platform types.

Several factors may account for the lower production estimates on Glorieuses. First, the observed lower $\mathrm{CaCO}_{3}$ carbonate production estimates in Glorieuses reflect a large amount of carbonate mud which has not been considered in our estimates, because, after winnowing from the platform, carbonate mud has been deposited in other areas outside the footprint of 
the mapped carbonate slope deposits. Secondly, because much of the Glorieuses platform is relatively deep, $(25 \%<10 \mathrm{~m}, 10 \mathrm{~m}<35 \%<20 \mathrm{~m})$, the average rate of carbonate production on the entire platform should be expected to be lower than for shallow water reef and platform facies where the most rapidly growing corals flourish (Hamylton et al., 2017; Perry et al., 2015, 2013). Third, most of the Glorieuses platform is occupied by non-coral reef carbonate facies, especially Halimeda meadows, which are generally considered to have a much lower carbonate production rate than the coral reef components of platforms, which are more intensely studied (Hamylton et al. 2017). Furthermore, the lack of oolites or other abiotic carbonate sediment particles observed on the platform, indicates that platform sediment production is limited to typical coral reef sediment producers. Finally, actualistic surveybased carbonate production estimates likely underestimate the long-term rates of carbonate export during rare, intense storm events (Hubbard et al. 1990, Hubbard 1992). The Glorieuses estimate, being a Holocene average, necessarily incorporates these, in the basinal calcituridites, although it is possible that not all of the sediment exported was retained within the calciturbidite fan system.

All these processes are also in agreement with the highstand shedding model (Droxler and Schlager, 1985), and confirms that "reflooding windows" at glacial terminations may very rapidly switch on carbonate production on platform tops and export the excess sediment to the deep-sea (Counts et al., 2019; Jorry et al., 2010). While many studies on carbonate basins have demonstrated that most of the calciturbidites are deposited during highstands (e.g.

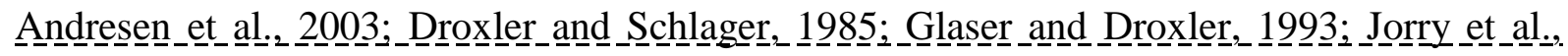
200ㅇ), our results at Glorieuses show that periods with low sea levels (e.g. MIS6 and MIS10) may have also experienced the export of carbonate sands into deep adjacent basins, as previously documented in the Northern Nicaragua Rise (Reijmer and Andresen, 2007), in the 
Exuma Sound, Bahamas (Reijmer et al., 2012, 2015), and along the Great Barrier Reef (PugaBernabéu et al., 2014). According to Reijmer and Andresen (2007), the increased coarsefraction percentage during glacials may be the result of various interacting processes such as a lower input of fine neritic sediments, redepositional processes at the upper slope during lowered sea level, and the export of this material to "proximal basinal" sites $(28 \mathrm{~km}$ in the basin adjacent to the Pedro Bank). At Glorieuses, it appears that the more frequent and thicker turbidites during MIS6 indicate that sediment was stored on ledges during MIS7 highstand, then re-exported as lowstand turbidites. This suggests that some calciturbidites behave like siliciclastic turbidites, with sediment accumulating at or slightly below the shelf break, then being removed during lowstands.

Based on observations on modern and fossil examples, fundamental differences in large-scale margin transitions and stratal patterns indicate contrasting ratios of material exported downslope relative to the volume of material required to fill the slope profile, creating significant lateral variations between leeward and windward margins in their degree of contribution to the foreslope (Eberli et al., 2004; Mullins, 1983; Playton et al., 2010). The general configuration of the Glorieuses platform shows that the sediment export is highly active toward the leeward margin, due to the influence of dominant trade winds. Despite any data have been acquired along the windward side, we may anticipate that a significant difference exists in terms of storage and export capacity between both margins. This hypothesis can be supported by previous studies which showed that the leeward and windward settings responded differently to glacial-interglacial related variations in sea level (Rendle-Bühring and Reijmer, 2005).

Compared to ancient analogues, the Glorieuses carbonate system provides some close similarities in terms of size, seismic expression, sediment composition, and slope processes. 
The turbiditic system observed at Glorieuses is consistent with the classification of Playton et al. (2010) who proposed that grain-dominated facies extend for great distances along strike (up to 10 s of kilometers), as documented for Upper Aptian to Danian carbonates series outcropping at the Gargano Peninsula (SE Italy) where a bioclastic base-of-slope apron developed $25 \mathrm{~km}$ far from the platform edge (Hairabian et al., 2015). Our observations also clarify that channel-lobe complexes are characterized by lower slope to toe-of-slope onlaps and erosive channel-form morphologies on the slope that pass into mounded, non-erosive lobate bodies in distal settings (as described in the Miocene Sardinia Basin, Vigorito et al., 2005). At a smaller observation scale, sediment cores collected in the Glorieuses basin may also serve as analogues for grain-dominated deposit transport processes which are related to well-sorted hyperconcentrated and concentrated flow when finer grained fractions are present (see review based on outcrop features proposed by Mulder and Alexander (2001)), resulting in the expression of partial to full Bouma sequences (Figure 6C and Figure 6D).

\section{Conclusions}

Our study provides an estimate of the functioning of a modern carbonate routing system located in the SW Indian Ocean, which helps to improve our knowledge of the processes related to the production, storage, and export of carbonate sediments from the platform top to the deep sea.

The Glorieuses case study clearly illustrates the physiographic connection between the platform top, the slope and the adjacent basin where shed carbonate products are collected. Our findings conclude that a large proportion (about 1/2) of the production of the carbonate platform during the Holocene has been exported downslope, the remaining $1 / 2$ of the 
production being stored on the platform top, in the form of on windward terraces, a sand apron composed of migrating sand dunes, and dominantly along the leeward edge where subtidal dunes are accumulated.

During the last two climatic cycles, calciturbidites have been deposited during successive lowstands and highstands, being transferred to the deep-sea through channels and deposited on lobes, with a maximum extent of $50 \mathrm{~km}$ into the abyssal plain. We note that the thickest sand deposits are transferred mainly during high sea levels when the platform top was flooded, in particular during MIS 7. Deposition of turbidites also occurred during glacial stages and was particularly important during MIS 6, mainly at proximal locations in the turbidite system, which may imply some reworking processes occurring along the upper slope.

The annual carbonate production calculated from the overall Holocene production on the Glorieuses platform $\left(9.27 \cdot 10^{8} \mathrm{~mol} . \mathrm{km}^{-2}\right)$ was slightly lower but close to what has been proposed in the literature for modern reefs and carbonate platforms. We conclude that such small-size carbonate platforms can potentially illustrate the carbonate budget in the ocean, at a regional or global scale.

\section{Data availability}

Sediment cores collected in the Glorieuses basin are curated at IFREMER core repository in Plouzané (France). Core data related to this article can be requested at:

Core PAMELA-MOZ1-KS04: IGSN BFBGX-127668 (http://igsn.org/BFBGX-127668)

Core PAMELA-MOZ1-KS07: IGSN BFBGX-127671 (http://igsn.org/BFBGX-127671) 
Dataset including isotope data, age model, and aragonite $\%$ of the two cores are available at: https://doi.org/10.17882/71021

\section{Acknowledgements}

We are grateful to PTOLEMEE (PI: S. Jorry) and PAMELA-MOZ1 (PI: K. Olu) cruise participants, to CTDI (Ifremer) for bathymetry grid processing and to O. Lebau and R. Courvaisier (University of Brest) who ran oxygen isotopes analyses. Y. Thomas and E. Thereau (IFREMER) are warmly thanked for seismic processing, as well as A. Boissier and S. Cheron (IFREMER) for XRF and XRD acquisition and interpretation. PTOLEMEE and PAMELA-MOZ1 cruises, and E. Miramontes' postdoctoral fellowship were co-funded by TOTAL and IFREMER as part of the PAMELA (Passive Margin Exploration Laboratories) project, in collaboration with IFPEN, Université de Rennes, Université de Brest, UPMC, and CNRS. The REEFCORES program was cofunded by France's "Iles Eparses" program (20112013), CEREGE, IFREMER, and TOTAL (FR00006152). Part of this research including J. Counts' postdoctoral fellowship was also funded by by the "Laboratoire d'Excellence" LabexMER (ANR-10-LABX-19) and cofounded by a grant from the French Government under the program "Investissements d'Avenir," and by a grant from the Regional Council of Brittany (SAD programme). E. Edinger's contributions to the paper were made during a sabbatical leave at IFREMER, funded by a Memorial University of Newfoundland sabbatical research grant, and by an NSERC Discovery Grant. Associate Editor Vittorio Maselli and both reviewers John Reijmer and Angel Puga-Bernabéu are acknowledged for their comments contributing to improve the original manuscript. 


\section{List of figures}

Figure 1: (A) Location of the Glorieuses archipelago in the SW Indian Ocean, north of Madagascar. (B) Satellite image of the Glorieuses archipelago (Google Earth) and bathymetry acquired along slopes and adjacent basin. The black dashed lines underline turbiditic lobes deposited into the deep basin. The red lines and arrows describe the canyon network and sediment pathways connected to the distal lobes. Black lines represent seismic lines acquired in that region, and are shown in Figure 5. Yellow circles correspond to the location of sediment cores. (C) Diagram showing maximal daily wind velocity registered at the Météofrance station in Glorieuses, from January 2007 to November 2013. (D) Back-scattered image acquired on the leeward slope of Glorieuses platform. Data are shown with high backscatter in black, interpreted as the presence of a coarse-grained sediment blanket. Red lines refer to transfer axes shown on B. (E) Detailed bathymetry acquired along the northwestern edge of the Glorieuses platform, indicating the presence of submarine sand dunes deposited along the platform edge.

Figure 2: Current at 60-150 m water depth from a hull-mounted ADCP (A) and wind velocity from the vessel meteorological station (B) acquired during the 2014 Ptolemee cruise. (C) Satellite image of the Glorieuses archipelago showing bank-derived carbonate sediment plume being exported offshore (Prat et al., 2016). The white dashed line corresponds to the platform edge.

Figure 3: (A) Map of the Glorieuses platform showing the main depositional environments (modified after Jorry et al., 2016). Black dots correspond to surface sediment samples collected in the Archipelago, which have been used to characterize bottom types and biota (cf. 
Prat et al., 2016). White dots correspond to sediment cores collected on the platform top, in intertidal settings. Small black dots within the fore-reef facies are coral pinnacles. (B) Satellite image (Google Map) of the Glorieuses platform and back-scattered image acquired along adjacent slopes. The red lines represent the seismic survey done on the Glorieuses platform during the REEFCORES 2 and REEFCORES 3 cruises. The green lines with numbers correspond to seismic profiles illustrated in Figure 4. Yellow areas represent the main sediment depocenters which have been deduced from interpretation of the seismic lines.

Figure 4: Illustration of sparker seismic lines acquired on the Glorieuses platform. (A) and (B) represent respectively processed and interpreted seismic profile acquired along the back-reef. (C) and (D) correspond respectively to processed and interpreted seismic profile acquired along the leeward platform edge. (E) Seismic profile (interpreted in (F)) acquired on submerged terraces located at the north-eastern edge of the Glorieuses platform. The location of the seismic profiles A, B, and C can be found on Figure 3.

Figure 5: (A) and (C) are seismic profiles acquired in the Glorieuses basin, with interpretation in (B) and (D). Location of these profiles can be seen in Figure 1B. Both profiles show a combination of sedimentary features atop the clearly defined volcanic basement, notably sandy turbidite lobes, identified by their better-organized and mixed-to high-amplitude reflections, that pinch out distally over the course of tens of kilometres. Chaotically bedded, low amplitude debris flows can also be seen in Figure 5A and 5B (labelled). These gravityflow deposits interfinger with the evenly bedded, fine-grained pelagic sediments.

Figure 6: (A) and (B) Sedimentological description and Sr XRF record of two sediment cores collected in the Glorieuses basin (see core location on Figure 1). Yellow facies correspond to 
calciturbidites, and carbonate mud correspond to orange facies. Blue dots represent radiocarbon dates and corresponding ages (cal BP). The location of both cores can be found in Figure 1. (C) and (D) represent pictures (left) and XCT (right) of two calciturbidite sequences identified on the two sediment cores, characterized by typical laminated, fining-upward sequences. (E) Petrographic content of a calciturbidite sampled in core MOZ1-KS04 (at $245 \mathrm{~cm})$. (F) Petrographic content of sediment sampled on the apron of the Glorieuses archipelago (core top of RC-GLO-C030, see Figure 1 and 3 for location).

Figure 7: Relationships between the WD-XRF Sr (ppm) and the XRD Aragonite (\%), and the WD-XRF Sr (ppm) with the XRF-CS Sr (counts). R2 indicates the correlation coefficient for each linear regression. The black squares indicate Holocene samples.

Figure 8: Density from cores collected in the Glorieuses basin (A) and on the platform top (B).

Figure 9: Summary diagram illustrating the sediment volume partitioning in Glorieuses since the last reflooding of the platform, from platform top to deep basin. Estimates show that the Glorieuses platform has produced about $0.57 \mathrm{~km}^{3}$ of sediment, with $0.3 \mathrm{~km}^{3}$ presently stored on the platform top, and $0.27 \mathrm{~km}^{3}$ being exported downslope and deposited in the adjacent basin.

Figure 10: Timing of sandy turbidites and aragonite deposition across the last three glacialinterglacial cycles. (A) Late Pleistocene sea-level stack in blue (Spratt and Lisiecki, 2016). The dashed black line centered on $-60 \mathrm{~m}$ water depth represents the mean depth of the Glorieuses platform edge. The red line represents the aragonite flux calculated along core 
MOZ1-KS04. B: Planktonic oxygen isotopes along core MOZ1-KS04, with numbers corresponding to isotopic stages. Blue circles and associated numbers indicate radiocarbon dates with corresponding ages (cal BP). Bands crossing (A) and (B) represent the base of the calciturbidites identified along core MOZ1-KS04, which were deposited during glacial (orange bands) or interglacial (yellow bands) periods. (C) Late Pleistocene sea-level stack in blue (Spratt and Lisiecki, 2016), with numbers corresponding to isotopic stages, and planktonic oxygen isotopes (white circles) along core MOZ1-KS07. The dashed black line centred on $-60 \mathrm{~m}$ water depth represents the mean depth of the Glorieuses platform edge. Bands represent the base of the calciturbidites identified along core MOZ1-KS07, which were deposited during glacial (orange bands) or interglacial (yellow bands) periods. Turbidite thicknesses and frequencies have been calculated for both MOZ1-KS04 (D) and MOZ1-KS07 (E) sediment cores. Both diagrams illustrate cumulative thickness and number of calciturbidites recognized in each marine isotope stages (MIS), for periods when the Glorieuses platform was flooded (interglacials) or exposed (glacials).

\section{List of tables}

Table 1: Radiocarbon dates for cores MOZ1-KS04 and MOZ1-KS07, collected in the Glorieuses basin, and for surface sediment RC-GLO-B248 collected on the leeward platform edge, at $31 \mathrm{~m}$ water depth. ${ }^{14} \mathrm{C}$ ages were calibrated using the Marine13 radiocarbon age calibration curve (Reimer et al., 2013).

Table 2: Main facies areas of the Glorieuses platform and gross productivity estimate $(\mathrm{G}$, expressed in $\left.\mathrm{g} \cdot \mathrm{CaCO}_{3} \cdot \mathrm{m}^{-2} \cdot \mathrm{d}^{-1}\right)$. * This factor of 2 is a rough estimate based on the depthrelated differences in carbonate productivity reported in Vecsei (2004), comparing values of 
shallower than $20 \mathrm{~m}$ vs deeper than $20 \mathrm{~m}$. Vecsei's estimates in turn depend partly on depthrelated differences in individual coral species growth rates (Bosscher and Meesters, 1993).

Table 3: Glorieuses volume and mass of sediment stored on platform sand bodies and exported in submarine fans. Estimates for Holocene mud samples take into account a composition of $32 \%$ aragonite of the average of 2 cores with a total of 3 samples.

Table 4: Glorieuses volume and mass of sediment produced during Holocene compared with global and regional reef production estimates. ${ }^{*} \mathrm{NB}$ : these results are based on the assumption that the measured value of $32 \%$ aragonite in basin muds corresponds to the proportion of aragonite muds derived from the platform, i.e. assuming that the majority of the platform sediments are aragonite, and include only the mud within the footprint of the basin sediment lobes. 
Table 1

\begin{tabular}{|c|c|c|c|c|c|c|}
\hline Core label & $\begin{array}{l}\text { Depth } \\
\text { (cm) }\end{array}$ & Lab. Number & Species & $\begin{array}{l}{ }^{14} \mathrm{C} \text { age } \\
(\mathrm{yr} B P)\end{array}$ & $\begin{array}{l}\text { error } \\
(1 \sigma)\end{array}$ & $\begin{array}{c}\text { Calendar age } \\
\quad(\mathrm{yr} \mathrm{BP})\end{array}$ \\
\hline MOZ1-KS04 & 10 & Beta-409928 & G. ruber & 5,450 & 30 & 5,692 \\
\hline MOZ1-KS04 & 40 & Beta-423385 & G. ruber & 9,940 & 30 & 10,768 \\
\hline MOZ1-KS04 & 60 & Beta-423386 & G. ruber & 15,750 & 50 & 18,505 \\
\hline MOZ1-KS04 & 70 & Beta-423387 & G. ruber & 21,690 & 80 & 25,486 \\
\hline MOZ1-KS04 & 105 & Beta-423388 & G. ruber & 38,680 & 410 & 42,345 \\
\hline MOZ1-KS07 & 0 & Beta-475302 & G. ruber & 8,240 & 40 & 8,574 \\
\hline MOZ1-KS07 & 24 & Beta-475303 & G. ruber & 9,750 & 30 & 10,471 \\
\hline MOZ1-KS07 & 54 & Beta-475304 & G. ruber & 16,380 & 60 & 19,186 \\
\hline MOZ1-KS07 & 120 & Beta-475305 & G. ruber & 43,320 & 650 & 46,162 \\
\hline RC-GLO-B248A & 0 & Beta-361147 & A. lessonii & 1,430 & 30 & 835 \\
\hline RC-GLO-B248B & 0 & Beta-361148 & A. lessonii & 1,560 & 30 & 950 \\
\hline RC-GLO-B248C & 0 & Beta-361149 & A. lessonii & 1,410 & 30 & 810 \\
\hline
\end{tabular}

Table 2

\begin{tabular}{|c|c|c|c|c|}
\hline Facies & Area (\%) & Area $\left(\mathbf{k m}^{2}\right)$ & $\begin{array}{l}\text { Productivity } \\
\text { (G) }\end{array}$ & Source for $\mathrm{CaCO}_{3}$ Productivity Estimate \\
\hline islands & 2.5 & 4.79 & 0 & $\mathrm{n} / \mathrm{a}$ \\
\hline reef flat & 11.1 & 20.85 & 1.66 & Leon and Woodroffe (2013) \\
\hline reef front & 17 & 31.97 & 4 & Kinsey and Hopley (1991) \\
\hline apron & 5.8 & 10.9 & 0.2 & Cyronak et al $\underline{\text { al }}$ (2013) in Hamylton et al. (2017) \\
\hline shallow inner platform & 11.4 & 21.34 & 2.2 & Rees et al. (2007) in Hamylton et al. (2017) \\
\hline deep inner platform & 27 & 50.78 & 1.1 & Half of shallow inner platform* \\
\hline fore-reef & 25.2 & 47.38 & 2.2 & Vecsei (2004) \\
\hline $\begin{array}{l}\text { Total Area / weighted } \\
\text { average production rate }\end{array}$ & 100 & 188.01 & 1.76 & $\mathrm{n} / \mathrm{a}$ \\
\hline
\end{tabular}

\section{Table 3}

\begin{tabular}{|c|c|c|c|c|c|c|c|c|}
\hline Location & $\begin{array}{l}\text { Sediment body } \\
\text { (Holocene) }\end{array}$ & $\operatorname{Area}\left(\mathbf{m}^{2}\right)$ & $\begin{array}{l}\text { Average } \\
\text { thickness } \\
\text { (m) }\end{array}$ & $\begin{array}{c}\% \\
\text { aragonite }\end{array}$ & $\begin{array}{l}\text { Volume } \\
\left(\mathbf{m}^{3}\right)\end{array}$ & $\begin{array}{l}\text { Density } \\
\left(\mathrm{kg} / \mathrm{m}^{3}\right)\end{array}$ & $\mathrm{Kg} \mathrm{CaCO}_{3}$ & $\mathrm{Mol} \mathrm{CaCO}_{3}$ \\
\hline Platform & Sand lenses & $18.8 \cdot 10^{6}$ & & $100 \%$ & $3.0 \cdot 10^{8}$ & $1603.9 \pm 25$ & $4.81 \cdot 10^{11}$ & $4.80 \cdot 10^{12}$ \\
\hline \multirow{3}{*}{ Basin } & $\begin{array}{l}\text { All sediment in } \\
\text { fans }\end{array}$ & $600 \cdot 10^{6}$ & 0.92 & -- & $5.52 \cdot 10^{8}$ & $1590 \pm 9.5$ & $8.77 \cdot 10^{11}$ & $8.77 \cdot 10^{12}$ \\
\hline & $\begin{array}{l}\text { Calci-turbidite } \\
\text { sands }\end{array}$ & $600 \cdot 10^{6}$ & 0.23 & $100 \%$ & $1.38 \cdot 10^{8}$ & $1640 \pm 86$ & $2.26 \cdot 10^{11}$ & $2.26 \cdot 10^{12}$ \\
\hline & Carbonate muds & $600 \cdot 10^{6}$ & 0.69 & $32 \%$ & $1.32 \cdot 10^{8}$ & $1655 \pm 45$ & $2.19 \cdot 10^{11}$ & $2.19 \cdot 10^{12}$ \\
\hline
\end{tabular}


Table 4

\begin{tabular}{|c|c|c|c|c|c|c|c|c|}
\hline $\begin{array}{l}\text { Author } \\
\text { (year) }\end{array}$ & Scale & $\begin{array}{l}\mathrm{CaCO}_{3} \\
\text { production } \\
(\mathrm{mol} / \mathrm{y})\end{array}$ & $\begin{array}{l}\mathrm{CaCO}_{3} \\
\text { production } \\
(\mathrm{Gt} / \mathrm{y})\end{array}$ & $\begin{array}{l}\text { Area } \\
\left(\mathbf{k m}^{2}\right)\end{array}$ & $\begin{array}{l}\text { Production } \\
\text { rate } \\
\left(\mathbf{m o l}, \mathbf{k g} / \mathbf{k m}^{2} / \mathbf{y}\right)\end{array}$ & $\begin{array}{l}\text { Applied to } \\
\text { Glorieuses } \\
(\mathbf{m o l}, \mathrm{kg} / \mathrm{y})\end{array}$ & $\begin{array}{l}\text { Glorieuses } \\
\text { estimate (this } \\
\text { study)* } \\
(\mathrm{mol}, \mathrm{kg} / \mathrm{y})\end{array}$ & $\begin{array}{l}\% \text { of } \\
\text { regional } \\
\text { or global } \\
\text { rate } \\
\end{array}$ \\
\hline $\begin{array}{l}\text { Milliman } \\
\text { (1993) }\end{array}$ & Global & $9.0 \cdot 10^{12}$ & $\mathrm{n} / \mathrm{a}$ & $6.0 \cdot 10^{5}$ & $1.50 \cdot 10^{7} \mathrm{~mol}$ & $2.75 \cdot 10^{9} \mathrm{~mol}$ & $9.26 \cdot 10^{8} \mathrm{~mol}$ & 33.73 \\
\hline $\begin{array}{l}\text { Kleypas } \\
(1997)\end{array}$ & Global & $\mathrm{n} / \mathrm{a}$ & $0.9-1.68$ & $6.65 \cdot 10^{5}$ & $2.07 \cdot 10^{6} \mathrm{~kg}$ & $3.80 \cdot 10^{8} \mathrm{~kg}$ & & 24.37 \\
\hline $\begin{array}{l}\text { Vecsei } \\
(2004)\end{array}$ & Global & $\mathrm{n} / \mathrm{a}$ & 0.73 & $3.037 \cdot 10^{5}$ & $2.40 \cdot 10^{6} \mathrm{~kg}$ & $4.40 \cdot 10^{8} \mathrm{~kg}$ & & 21.04 \\
\hline $\begin{array}{l}\text { Leon \& } \\
\text { Woodroffe } \\
(2013)\end{array}$ & $\begin{array}{l}\text { Regional } \\
\text { (Torres } \\
\text { Strait; } \\
\text { crescentic } \\
\text { only }\end{array}$ & & $3.2 \times 10^{-6}$ & 961 & $3.3 \cdot 10^{6} \mathrm{~kg}$ & $6.10 \cdot 10^{8} \mathrm{~kg}$ & $9.27 \cdot 10^{7} \mathrm{~kg}$ & 15.19 \\
\hline $\begin{array}{l}\text { Hamylton et } \\
\text { al. (2017) }\end{array}$ & $\begin{array}{l}\text { Regional } \\
\text { (GBR, all } \\
\text { reef types }\end{array}$ & $\mathrm{n} / \mathrm{a}$ & $4.8 \cdot 10^{-7}$ & 181 & $2.7 \cdot 10^{6} \mathrm{~kg}$ & $4.95 \cdot 10^{8} \mathrm{~kg}$ & & 18.72 \\
\hline $\begin{array}{l}\text { Perry et al. } \\
\text { (2015) }\end{array}$ & $\begin{array}{l}\text { Local } \\
\text { (Chagos) }\end{array}$ & $\mathrm{n} / \mathrm{a}$ & $\mathrm{n} / \mathrm{a}$ & $\mathrm{n} / \mathrm{a}$ & $3.7 \cdot 10^{6} \mathrm{~kg}$ & $6.78 \cdot 10^{8} \mathrm{~kg}$ & & 13,67 \\
\hline
\end{tabular}




\section{References}

Andersson, A.J., Gledhill, D., 2013. Ocean acidification and coral reefs: Effects on breakdown, dissolution, and net ecosystem calcification, in: Carlson, C.A., Giovannoni, S.J. (Eds.), Ann. Rev. Mar. Sci. 5, pp. 321-348.

Andresen, N., Reijmer, J.J.G., Droxler, A.W., 2003. Timing and distribution of calciturbidites around a deeply submerged carbonate platform in a seismically active setting (Pedro Bank, Northern Nicaragua Rise, Caribbean Sea). Int. J. Earth Sci. 92, 573-592.

Betzler, C., Lindhorst, S., Eberli, G.P., Lüdmann, T., Möbius, J., Ludwig, J., Schutter, I., Wunsch, M., Reijmer, J.J.G., Hübscher, C., 2014. Periplatform drift: The combined result of contour current and off-bank transport along carbonate platforms. Geology 42, 871-874.

Betzler, C., Reijmer, J.J.G., Bernet, K., Eberli, G.P., Anselmetti, F.S., 1999. Sedimentary patterns and geometries of the Bahamian outer carbonate ramp (Miocene-Lower Pliocene, Great Bahama Bank). Sedimentology 46, 1127-1143.

Bintanja, R., van de Wal, R.S.W., Oerlemans, J., 2005. Modelled atmospheric temperatures and global sea levels over the past million years. Nature 437, 125-128.

Blanchon, P., Shaw, J., 1995. Reef drowning during the last deglaciation: Evidence for catastrophic sea-level rise and ice-sheet collapse. Geology 23, 4.

Bornhold, B.D., Pilkey, O.H., 1971. Bioclastic turbidite sedimentation in Columbus Basin, Bahamas. GSA Bull. 82, 1341-1354.

Bosscher, H., Meesters, E.H., 1993. Depth related changes in the growth rate of Montastrea annularis, in: Proc 7th Int Coral Reef Symp., pp. 507-512.

Clark, P.U., McCabe, A.M., Mix, A.C., Weaver, A.J., 2004. Rapid rise of sea level 19,000 years ago and its global implications. Science 304, 1141-1144.

Counts, J.W., Jorry, S.J., Leroux, E., Miramontes, E., Jouet, G., 2018. Sedimentation adjacent to atolls and volcano-cored carbonate platforms in the Mozambique Channel (SW Indian Ocean). Mar. Geol. 404, 41-59.

Counts, J.W., Jorry, S.J., Vazquez Riveiros, N., Jouet, G., Giraudeau, J., Cheron, S., Boissier, A., Miramontes, E., 2019. A Late Quaternary record of highstand shedding from an isolated carbonate platform (Juan de Nova, southern Indian Ocean). Depositional Rec. 5, 540-557.

Courgeon, S., Jorry, S.J., Camoin, G.F., BouDagher-Fadel, M.K., Jouet, G., Revillon, S., Bachelery, P., Pelleter, E., Borgomano, J., Poli, E., Droxler, A.W., 2016. Growth and demise of Cenozoic isolated carbonate platforms: New insights from the Mozambique Channel seamounts (SW Indian Ocean). Mar. Geol. 380, 90-105.

Crevello, P.D., Schlager, W., 1980. Carbonate debris sheets and turbidites, Exuma Sound, Bahamas. J. Sediment. Res. 50, 1121-1147. 
Cyronak, T., Santos, I.R., Eyre, B.D., 2013. Permeable coral reef sediment dissolution driven by elevated pCO2 and pore water advection. Geophys. Res. Lett. 40, 4876-4881.

Deschamps, P., Durand, N., Bard, E., Hamelin, B., Camoin, G., Thomas, A.L., Henderson, G.M., Okuno, J., Yokoyama, Y., 2012. Ice-sheet collapse and sea-level rise at the Bølling warming 14,600 years ago. Nature 483, 559-564.

Droxler, A., Schlager, W., 1985. Glacial versus interglacial sedimentation-rates and turbidite frequency. Geology 13, 799-802.

Dutton, A., Bard, E., Antonioli, F., Esat, T.M., Lambeck, K., McCulloch, M.T., 2009. Phasing and amplitude of sea-level and climate change during the penultimate interglacial. Nat.

Geosci. 2, 355-359.

Dutton, A., Lambeck, K., 2012. Ice volume and sea level during the Last Interglacial. Science 337, 216-219.

Eberli, G.P., Anselmetti, F.S., Betzler, C., Konijnenburg, J.-H.V., Bernoulli, D., 2004. Carbonate platform to basin transitions on seismic data and in outcrops: Great Bahama Bank and the Maiella Platform margin, Italy. AAPG Mem. 81, 207-250.

Eberli, G.P., Swart, P.K., Malone, M.J., Al, A.E., 1997a. Proceedings, initial reports, Ocean Drilling Program, Leg 166; Bahamas transect. ODP Tex. M Univ. Coll. Stn.

Eberli, G.P., Swart, P.K., McNeill, D.F., Kenter, J.A.M., Anselmetti, F.S., Melim, L.A., Ginsburg, R.N., 1997b. A synopsis of the Bahamas Drilling Project: Results from two deep core borings drilled on the Great Bahama Bank, in: Proceedings of the Ocean Drilling Program, Initial Reports. pp. 23-41.

Emerick, C., Duncan, R., 1982. Age Progressive volcanism in the Comores Archipelago, western Indian Ocean and implications for Somali plate-tectonics. Earth Planet. Sci. Lett. 60, 415-428.

Falkowski, P., Scholes, R.J., Boyle, E., Canadell, J., Canfield, D., Elser, J., Gruber, N., Hibbard, K., Hogberg, P., Linder, S., Mackenzie, F.T., Moore, B., Pedersen, T., Rosenthal, Y., Seitzinger, S., Smetacek, V., Steffen, W., 2000. The global carbon cycle: A test of our knowledge of earth as a system. Science 290, 291-296.

Gerland, S., Villinger, H., 1995. Nondestructive density determination on marine sediment cores from gamma-ray attenuation measurements. Geo-Mar. Lett. 15, 111-118.

Glaser, K., Droxler, A., 1993. Controls and development of Late Quaternary periplatform carbonate stratigraphy in Walton Basin (northeastern Nicaragua Rise, Caribbean Sea). Paleoceanography 8, 243-274.

Hairabian, A., Borgomano, J., Masse, J.-P., Nardon, S., 2015. 3-D stratigraphic architecture, sedimentary processes and controlling factors of Cretaceous deep-water resedimented carbonates (Gargano Peninsula, SE Italy). Sediment. Geol. 317, 116-136.

Hamylton, S.M., Duce, S., Vila-Concejo, A., Roelfsema, C.M., Phinn, S.R., Carvalho, R.C., 
Shaw, E.C., Joyce, K.E., 2017. Estimating regional coral reef calcium carbonate production from remotely sensed seafloor maps. Remote Sens. Environ. 201, 88-98.

Hanebuth, T., Stattegger, K., Grootes, P.M., 2000. Rapid flooding of the Sunda shelf: A lateglacial sea-level Record. Science 288, 1033-1035.

Hopley, D., 1982. The geomorphology of the Great Barrier Reef: Quaternary development of coral reefs, Wiley. ed. New York.

Hubbard, D., Miller, A., Scaturo, D., 1990. Production and cycling of calcium-carbonate in a shelf-edge reef system (st-Croix, United-States Virgin-Islands) - Applications to the nature of reef systems in the fossil record. J. Sediment. Petrol. 60, 335-360.

Hughes, T.P., 1999. Off-reef transport of coral fragments at Lizard Island, Australia. Mar. Geol. 157, 1-6.

Jorry, S.J., 2014. PTOLEMEE cruise, L'Atalante R/V. https://doi.org/10.17600/14000900

Jorry, S.J., Camoin, G.F., Jouet, G., Le Roy, P., Vella, C., Courgeon, S., Prat, S., Fontanier, C., Paumard, V., Boulle, J., Caline, B., Borgomano, J., 2016. Modern sediments and Pleistocene reefs from isolated carbonate platforms (Iles Eparses, SW Indian Ocean): A preliminary study. Acta Oecologica-Int. J. Ecol. 72, 129-143.

Jorry, S.J., Droxler, A.W., Francis, J.M., 2010. Deepwater carbonate deposition in response to re-flooding of carbonate bank and atoll-tops at glacial terminations. Quat. Sci. Rev. 29, 20102026.

Jorry, S.J., Droxler, A.W., Mallarino, G., Dickens, G.R., Bentley, S.J., Beaufort, L., Peterson, L.C., Opdyke, B.N., 2008. Bundled turbidite deposition in the central Pandora Trough (Gulf of Papua) since Last Glacial Maximum: Linking sediment nature and accumulation to sea level fluctuations at millennial timescale. J. Geophys. Res.-Earth Surf. 113, F01S19.

Jose, Y.S., Penven, P., Aumont, O., Machu, E., Moloney, C.L., Shillington, F., Maury, O., 2016. Suppressing and enhancing effects of mesoscale dynamics on biological production in the Mozambique Channel. J. Mar. Syst. 158, 129-139.

Kangwe, J., 2006. Calcareous algae of a tropical lagoon: Primary productivity, calcification and carbonate production. Department of Botany, Stockholm University, Sweden.

Kench, P.S., 1998. Physical controls on development of lagoon sand deposits and lagoon infilling in an Indian ocean atoll. J. Coast. Res. 14, 1014-1024.

Kenter, J. a. M., Anselmetti, F.S., Kramer, P.H., Westphal, H., Vandamme, M.G.M., 2002. Acoustic properties of young carbonate rocks, ODP Leg 166 and boreholes Clino and Unda, Western Great Bahama Bank. J. Sediment. Res. 72, 129-137.

Key, R.M., Kozyr, A., Sabine, C.L., Lee, K., Wanninkhof, R., Bullister, J.L., Feely, R.A., Millero, F.J., Mordy, C., Peng, T.-H., 2004. A global ocean carbon climatology: Results from Global Data Analysis Project (GLODAP). Glob. Biogeochem. Cycles 18. 
Kinsey, D.W., Hopley, D., 1991. The significance of coral reefs as global carbon sinks response to Greenhouse. Palaeogeogr. Palaeoclimatol. Palaeoecol. 89, 363-377.

Kleypas, J.A., 1997. Modeled estimates of global reef habitat and carbonate production since the Last Glacial Maximum. Paleoceanography 12, 533-545.

Kolla, V., Be, A., Biscaye, P., 1976. Calcium-carbonate distribution in surface sediments of the Indian Ocean. J. Geophys. Res.-Oceans Atmospheres 81, 2605-2616. 5

Lambeck, K., Chappell, J., 2001. Sea level change through the last glacial cycle. Science 292, 679-686.

Lea, D.W., Martin, P.A., Pak, D.K., Spero, H.J., 2002. Reconstructing a 350 ky history of sea level using planktonic $\mathrm{Mg} / \mathrm{Ca}$ and oxygen isotope records from a Cocos Ridge core. Quat. Sci. Rev. 21, 283-293.

Leon, J.X., Woodroffe, C.D., 2013. Morphological characterisation of reef types in Torres Strait and an assessment of their carbonate production. Mar. Geol. 338, 64-75.

Lisiecki, L.E., Raymo, M.E., 2005. A Pliocene-Pleistocene stack of 57 globally distributed benthic delta O-18 records. Paleoceanography 20, PA2007.

Macintyre, I., Graus, R., Reinthal, P., Littler, M., Littler, D., 1987. The barrier-reef sediment apron - Tobacco Reef, Belize. Coral Reefs 6, 1-12.

Maragos, J.E., Baines, G.B.K., Beveridge, P.J., 1973. Tropical cyclone Bebe creates a new land formation on Funafuti Atoll. Science 181, 1161-1164.

Milliman, J., 1993. Production and accumulation of calcium-carbonate in the Ocean - Budget. Glob. Biogeochem. Cycles 7, 927-957.

Milliman, J.D., Droxler, A.W., 1996. Neritic and pelagic carbonate sedimentation in the marine environment: Ignorance is not bliss. Geol. Rundsch. 85, 496-504.

Milliman, J.D., Droxler, A.W., 1995. Calcium carbonate sedimentation in the global Ocean: Linkages between the neritic and pelagic environments. Oceanography 8, 92-94.

Mulder, T., Alexander, J., 2001. Abrupt change in slope causes variation in the deposit thickness of concentrated particle-driven density currents. Mar. Geol. 175, 221-235.

Mulder, T., Ducassou, E., Eberli, G.P., Hanquiez, V., Gonthier, E., Kindler, P., Principaud, M., Fournier, F., Leonide, P., Billeaud, I., Marsset, B., Reijmer, J.J.G., Bondu, C., Joussiaume, R., Pakiades, M., 2012. New insights into the morphology and sedimentary processes along the western slope of Great Bahama Bank. Geology 40, 603-606.

Mulder, T., Ducassou, E., Gillet, H., Hanquiez, V., Principaud, M., Chabaud, L., Eberli, G.P., Kindler, P., Billeaud, I., Gonthier, E., Fournier, F., Leonide, P., Borgomano, J., 2014. First discovery of channel-levee complexes in a modern deep-water carbonate slope environment. J. Sediment. Res. 84, 1139-1146. 
Mullins, H., 1983. Base-of-slope carbonate aprons - An alternative to submarine fan model. Aapg Bull. 67, 521-521.

Mullins, H.T., Heath, K.C., Buren, H.M.V., Newton, C.R., 1984. Anatomy of a modern openocean carbonate slope: northern Little Bahama Bank. Sedimentology 31, 141-168.

Nougier, J., Cantagrel, J.M., Karche, J.P., 1986. The Comores archipelago in the western Indian Ocean: volcanology, geochronology and geodynamic setting. J. Afr. Earth Sci. 19835 , $135-144$.

Olu, K., 2014. PAMELA-MOZ01 cruise, L'Atalante R/V. https://doi.org/10.17600/14001000

Paillard, D., Labeyrie, L., Yiou, P., 1996. Macintosh Program performs time-series analysis. Eos Trans. Am. Geophys. Union 77, 379-379.

Perry, C.T., Kench, P.S., Smithers, S.G., Yamano, H., O’Leary, M., Gulliver, P., 2013. Time scales and modes of reef lagoon infilling in the Maldives and controls on the onset of reef island formation. Geology 41, 1111-1114.

Perry, C.T., Murphy, G.N., Graham, N.A.J., Wilson, S.K., Januchowski-Hartley, F.A., East, H.K., 2015. Remote coral reefs can sustain high growth potential and may match future sealevel trends. Sci. Rep. 5, 18289.

Playton, T.E., Janson, X., Kerans, C., 2010. Carbonate slopes. Facies Models 4, 449-476.

Prat, S., Jorry, S.J., Jouet, G., Camoin, G., Vella, C., Le Roy, P., Caline, B., Boichard, R., Pastol, Y., 2016. Geomorphology and sedimentology of a modern isolated carbonate platform: The Glorieuses archipelago, SW Indian Ocean. Mar. Geol. 380, 272-283.

Puga-Bernabéu, Á., Webster, J.M., Beaman, R.J., Reimer, P.J., Renema, W., 2014. Filling the gap: A 60 ky record of mixed carbonate-siliciclastic turbidite deposition from the Great Barrier Reef. Mar. Pet. Geol. 50, 40-50.

Purdy, E.G., Gischler, E., 2005. The transient nature of the empty bucket model of reef sedimentation. Sediment. Geol. 175, 35-47.

Ramsey, C.B., 2009. Bayesian analysis of radiocarbon dates. Radiocarbon 51, 337-360.

Ramsey, C.B., 2008. Deposition models for chronological records. Quat. Sci. Rev. 27, 42-60.

Rees, S.A., Opdyke, B.N., Wilson, P.A., Fifield, L.K., 2005. Coral reef sedimentation on Rodrigues and the western Indian Ocean and its impact on the carbon cycle. Philos. Trans. Math. Phys. Eng. Sci. 363, 101-120.

Rees, S.A., Opdyke, B.N., Wilson, P.A., Henstock, T.J., 2007. Significance of Halimeda bioherms to the global carbonate budget based on a geological sediment budget for the Northern Great Barrier Reef, Australia. Coral Reefs 26, 177-188.

Reijmer, J.J.G., Andresen, N., 2007. Mineralogy and grain size variations along two carbonate margin-to-basin transects (Pedro Bank, Northern Nicaragua Rise). Sediment. Geol. 198, 327- 
Reijmer, J.J.G., Palmieri, P., Groen, R., 2012. Compositional variations in calciturbidites and calcidebrites in response to sea-level fluctuations (Exuma Sound, Bahamas). Facies 58, 493507.

Reijmer, J.J.G., Palmieri, P., Groen, R., Floquet, M., 2015. Calciturbidites and calcidebrites: Sea-level variations or tectonic processes? Sediment. Geol. 317, 53-70.

Reimer, P.J., Bard, E., Bayliss, A., Beck, J.W., Blackwell, P.G., Ramsey, C.B., Buck, C.E., Cheng, H., Edwards, R.L., Friedrich, M., Grootes, P.M., Guilderson, T.P., Haflidason, H., Hajdas, I., Hatte, C., Heaton, T.J., Hoffmann, D.L., Hogg, A.G., Hughen, K.A., Kaiser, K.F., Kromer, B., Manning, S.W., Niu, M., Reimer, R.W., Richards, D.A., Scott, E.M., Southon, J.R., Staff, R.A., Turney, C.S.M., van der Plicht, J., 2013. Intcal13 and Marine13 radiocarbon age calibration curves 0-50,000 years Cal BP. Radiocarbon 55, 1869-1887.

Rendle-Bühring, R.H., Reijmer, J.J.G., 2005. Controls on grain-size patterns in periplatform carbonates: Marginal setting versus glacio-eustacy. Sediment. Geol. 175, 99-113.

Schlager, W., Reijmer, J., Droxler, A., 1994. Highstand shedding of carbonate platforms. J. Sediment. Res. 64, 270-281.

Schott, F.A., McCreary, J.P., 2001. The monsoon circulation of the Indian Ocean. Prog. Oceanogr. 51, 1-123.

Schott, F.A., Xie, S.-P., McCreary, J.P., 2009. Indian Ocean circulation and climate variability. Rev. Geophys. 47, RG1002.

Spratt, R.M., Lisiecki, L.E., 2016. A Late Pleistocene sea level stack. Clim. Past 12, 1079_ 1092.

Swallow, J., Fieux, M., Schott, F., 1988. The boundary currents east and north of Madagascar .1. Geostrophic Currents and Transports. J. Geophys. Res.-Oceans 93, 4951-4962.

Thompson, W.G., Goldstein, S.L., 2005. Open-system coral ages reveal persistent suborbital sea-level cycles. Science 308, 401-404.

Vecsei, A., 2004. A new estimate of global reefal carbonate production including the forereefs. Glob. Planet. Change 43, 1-18.

Vigorito, M., Murru, M., Simone, L., 2005. Anatomy of a submarine channel system and related fan in a foramol/rhodalgal carbonate sedimentary setting: a case history from the Miocene syn-rift Sardinia Basin, Italy. Sediment. Geol. 174, 1-30.

Waelbroeck, C., Labeyrie, L., Michel, E., Duplessy, J.C., McManus, J.F., Lambeck, K., Balbon, E., Labracherie, M., 2002. Sea-level and deep water temperature changes derived from benthic foraminifera isotopic records. Quat. Sci. Rev. 21, 295-305.

Weaver, A.J., Saenko, O.A., Clark, P.U., Mitrovica, J.X., 2003. Meltwater pulse 1A from Antarctica as a trigger of the Bølling-Allerød warm interval. Science 299, 1709-1713. 
Webster, J.M., Beaman, R.J., Puga-Bernabeu, A., Ludman, D., Renema, W., Wust, R.A.J., George, N.P.J., Reimer, P.J., Jacobsen, G.E., Moss, P., 2012. Late Pleistocene history of turbidite sedimentation in a submarine canyon off the northern Great Barrier Reef, Australia. Palaeogeogr. Palaeoclimatol. Palaeoecol. 331, 75-89.

Wilson, P.A., Roberts, H.H., 1995. Density cascading: Off-shelf sediment transport, evidence and implications, Bahama Banks. J. Sediment. Res. 65.

Woodroffe, C.D., Grime, D., 1999. Storm impact and evolution of a mangrove-fringed chenier plain, Shoal Bay, Darwin, Australia. Mar. Geol. 159, 303-321.

Wunsch, M., Betzler, C., Lindhorst, S., Lüdmann, T., Eberli, G.P., 2017. Sedimentary dynamics along carbonate slopes (Bahamas archipelago). Sedimentology 64, 631-657.

Yamano, H., Kayanne, H., Matsuda, F., Tsuji, Y., 2002. Lagoonal facies, ages, and sedimentation in three atolls in the Pacific. Mar. Geol. 185, 233-247.

Yamano, H., Kayanne, H., Yonekura, N., Kudo, K., 2000. 21-year changes of backreef coral distribution: Causes and significance. J. Coast. Res. 16, 99-110.

\section{Declaration of interests}

$\square$ The authors declare that they have no known competing financial interests or personal relationships that could have appeared to influence the work reported in this paper.

$\square$ The authors declare the following financial interests/personal relationships which may be considered as potential competing interests:

Highlights:

- A first estimate of a carbonate source-to-sink system is proposed, from platform top to adjacent basin

- Neritic sands produced on platform top are mainly stored along the leeward platform edge 
- Carbonate sediments are exported in the basin through channel-levee complexes and deposited along turbiditic fans

- This carbonate routine systems was active during past glacial/interglacial cycles 

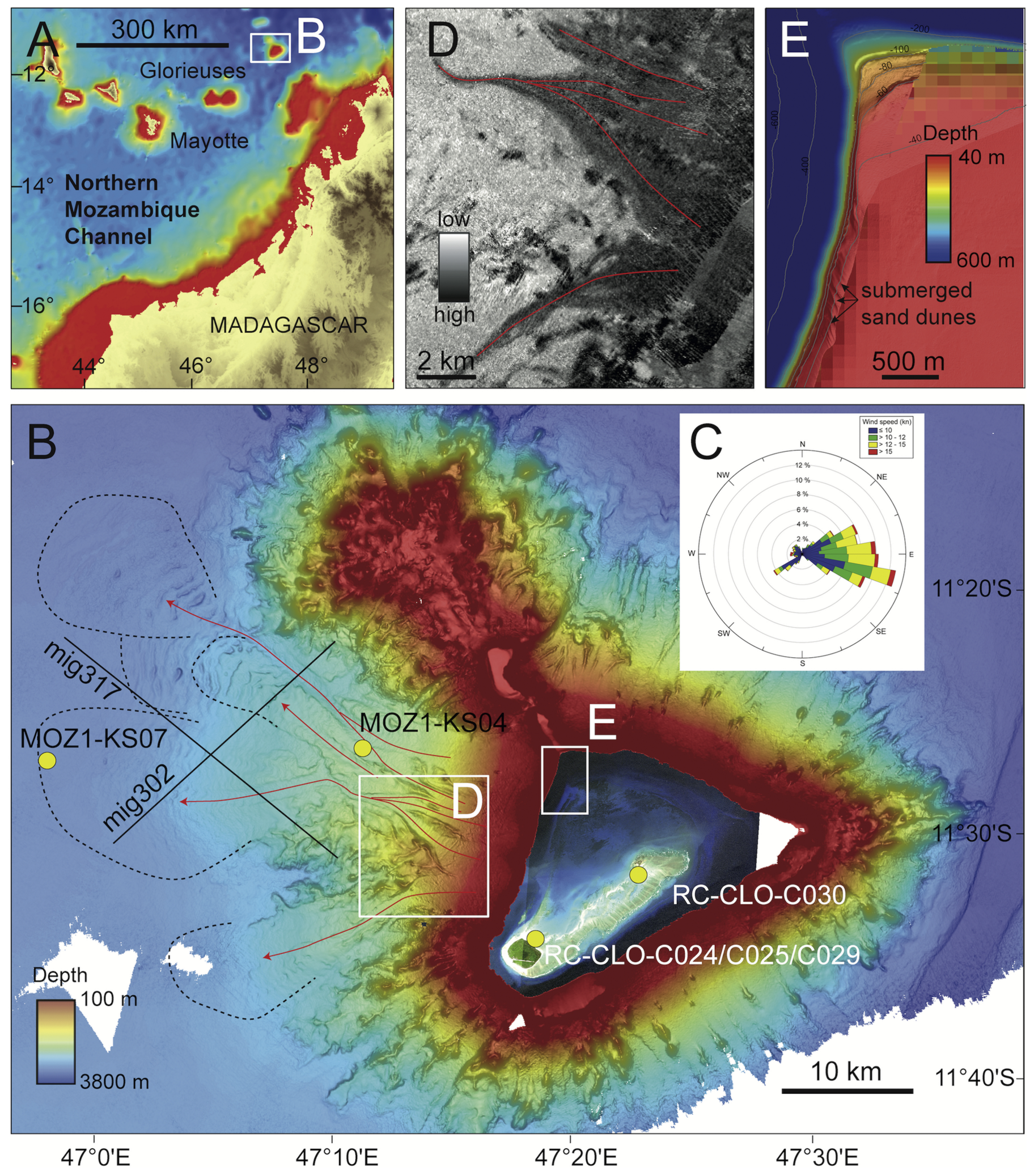


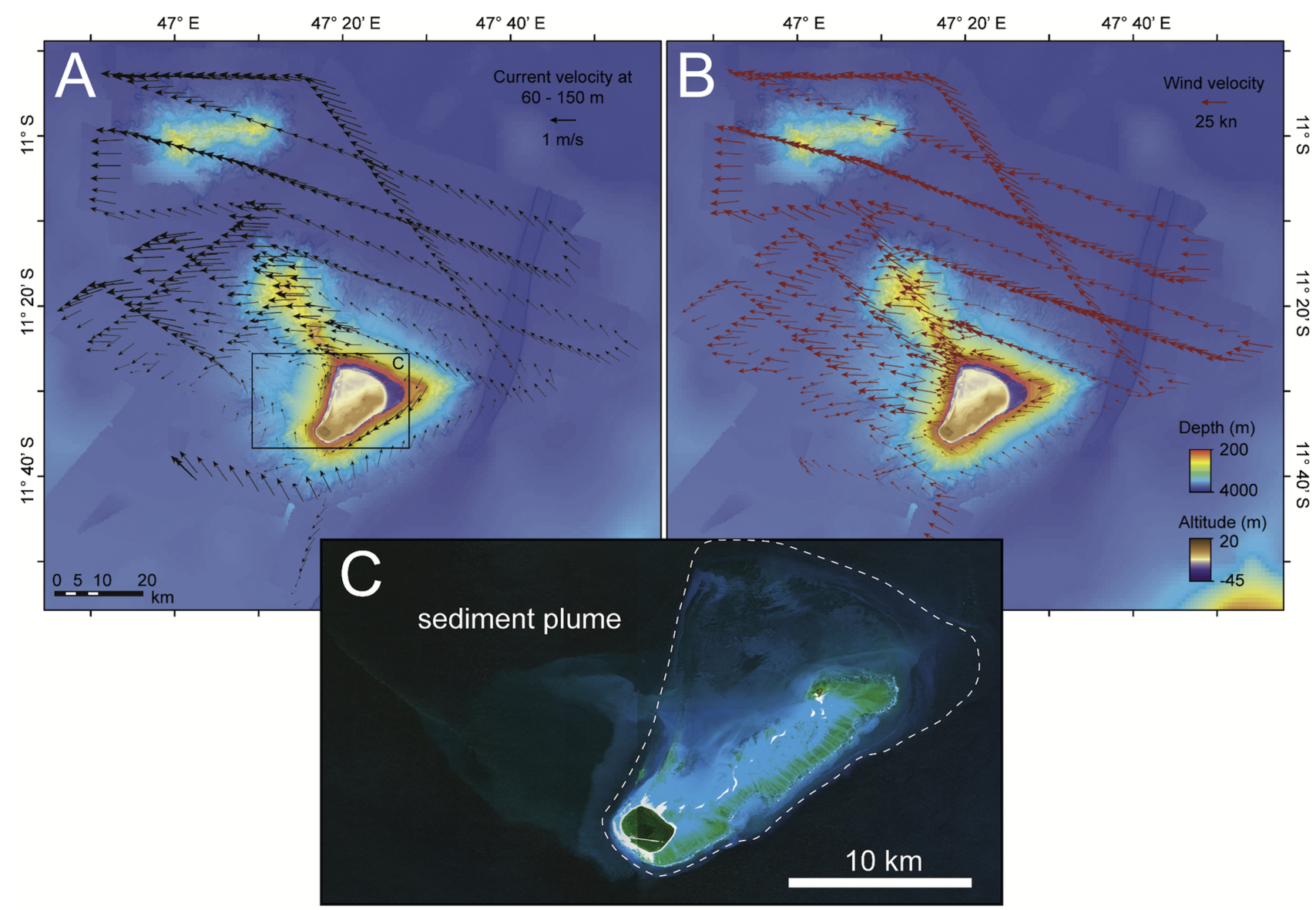

Figure 2 

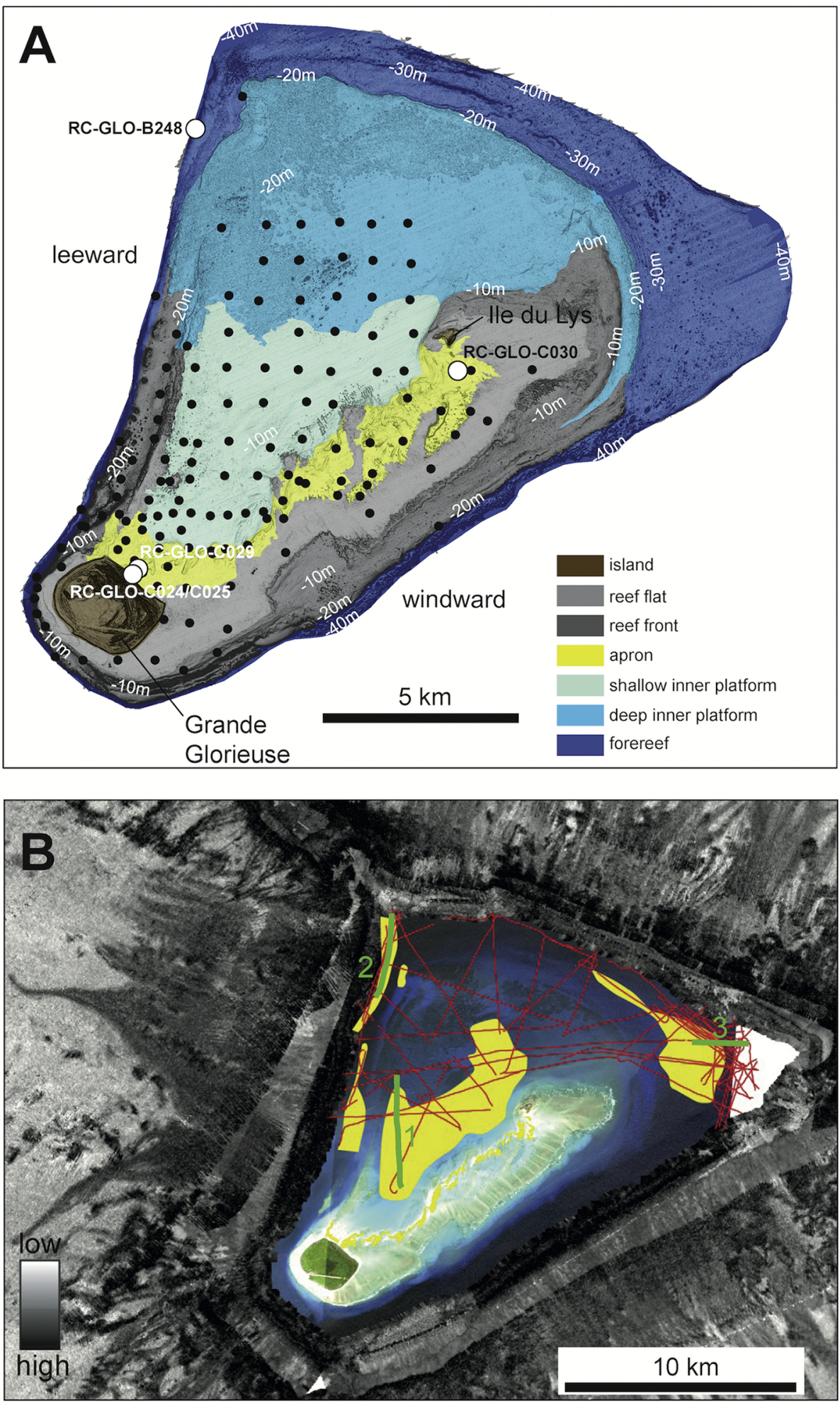

Figure 3 

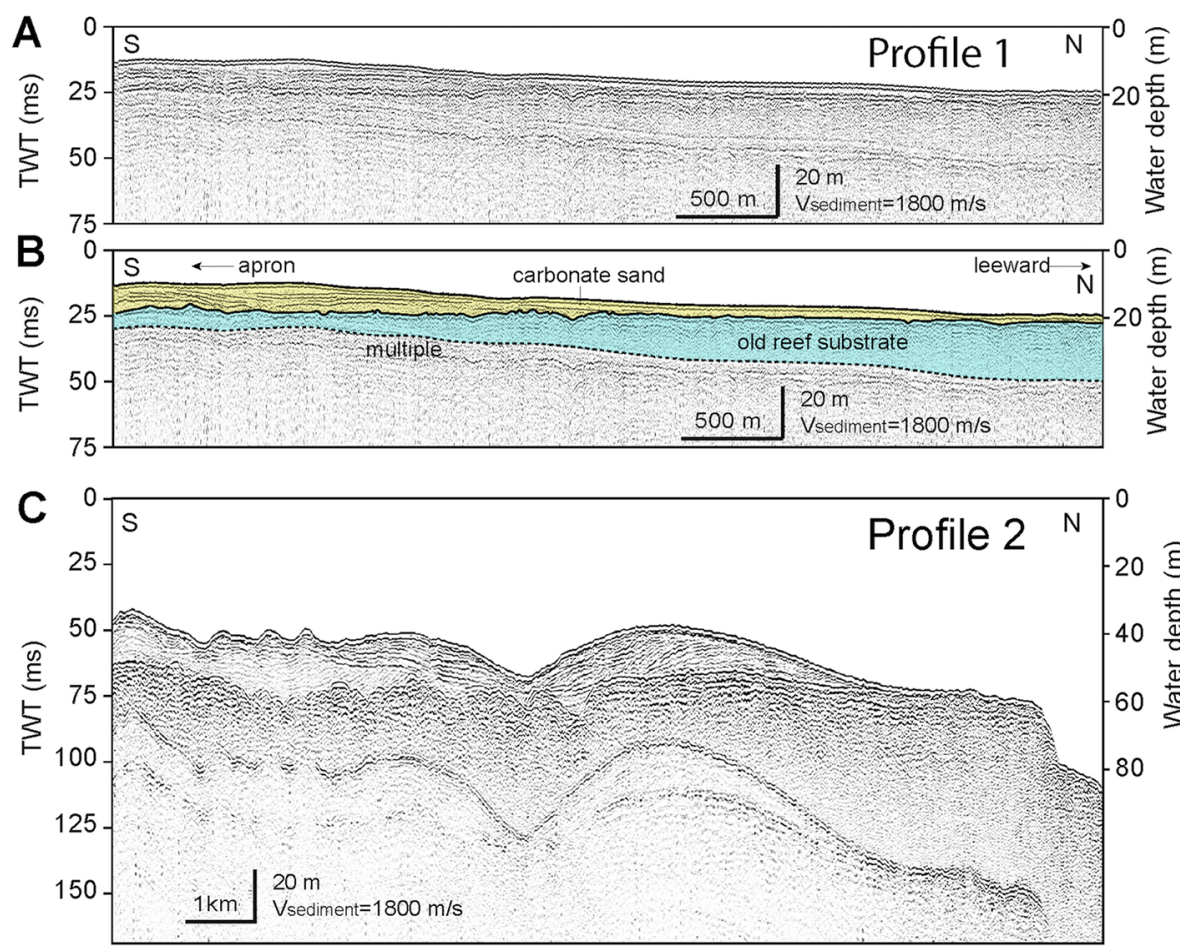

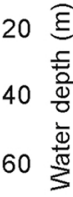
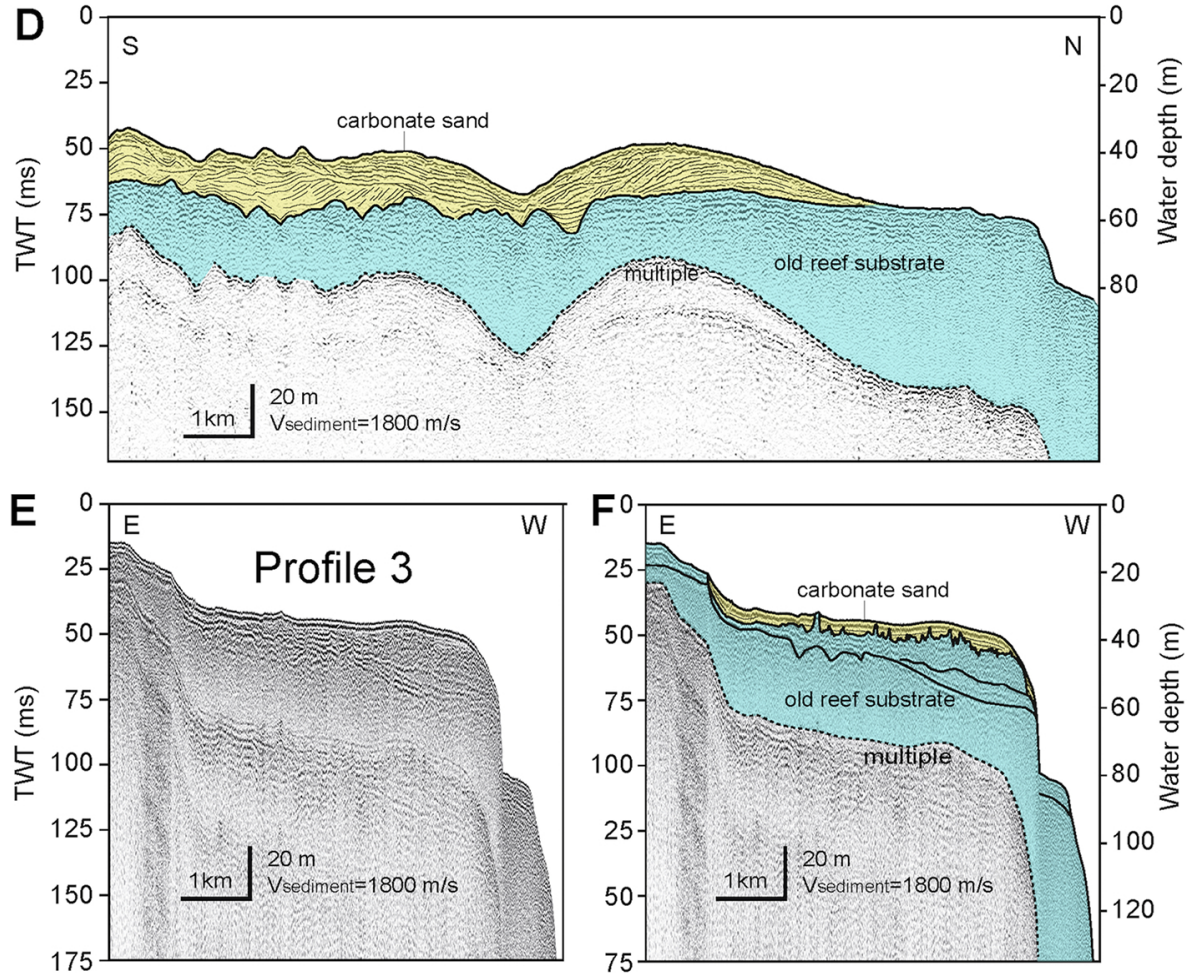

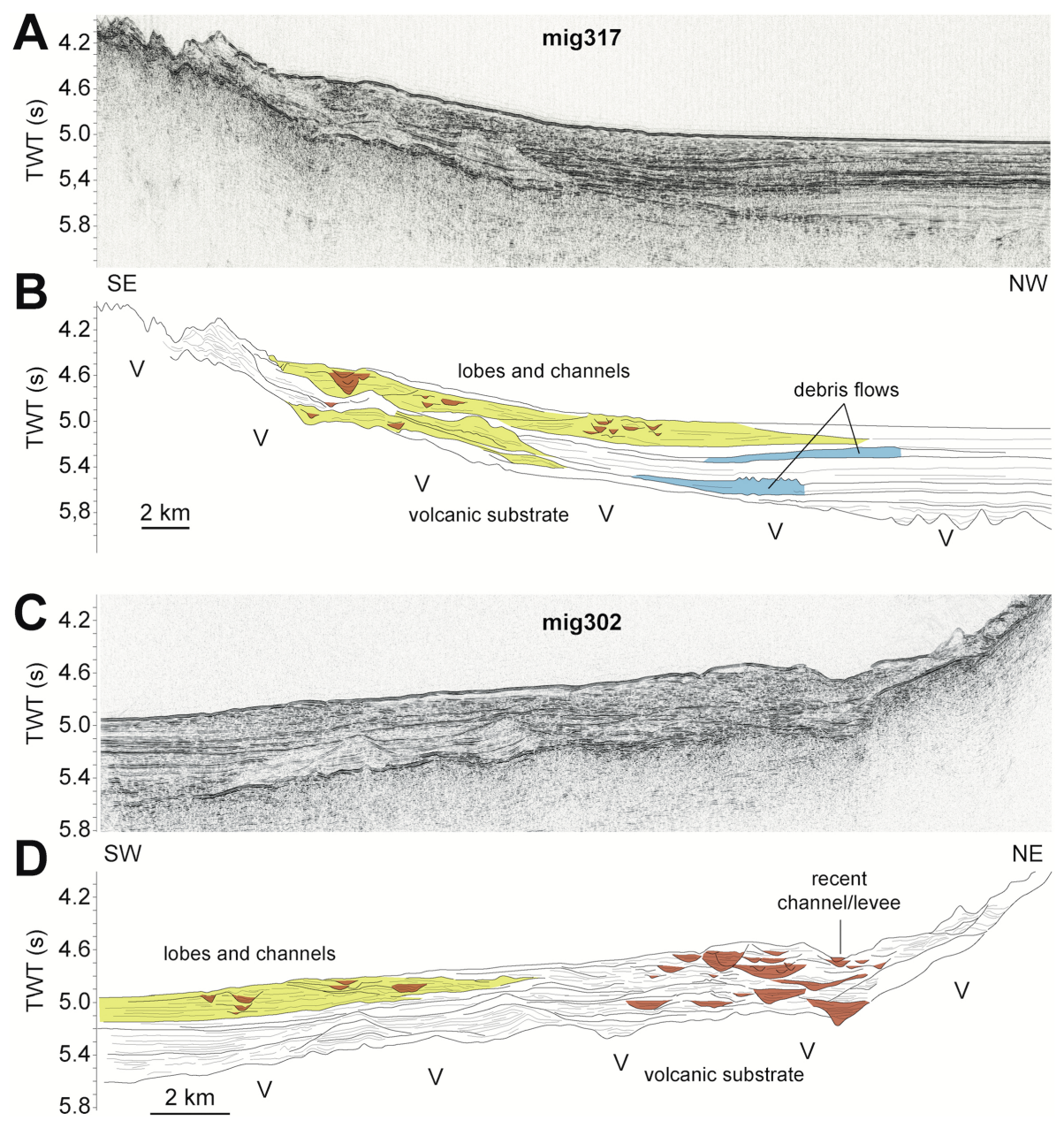

Figure 5 


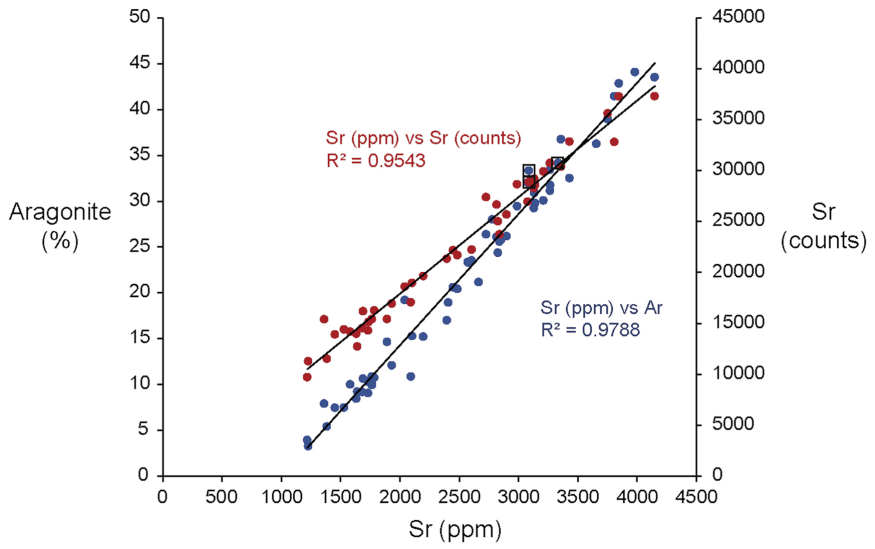

Figure 7 
A

GLORIEUSES BASIN

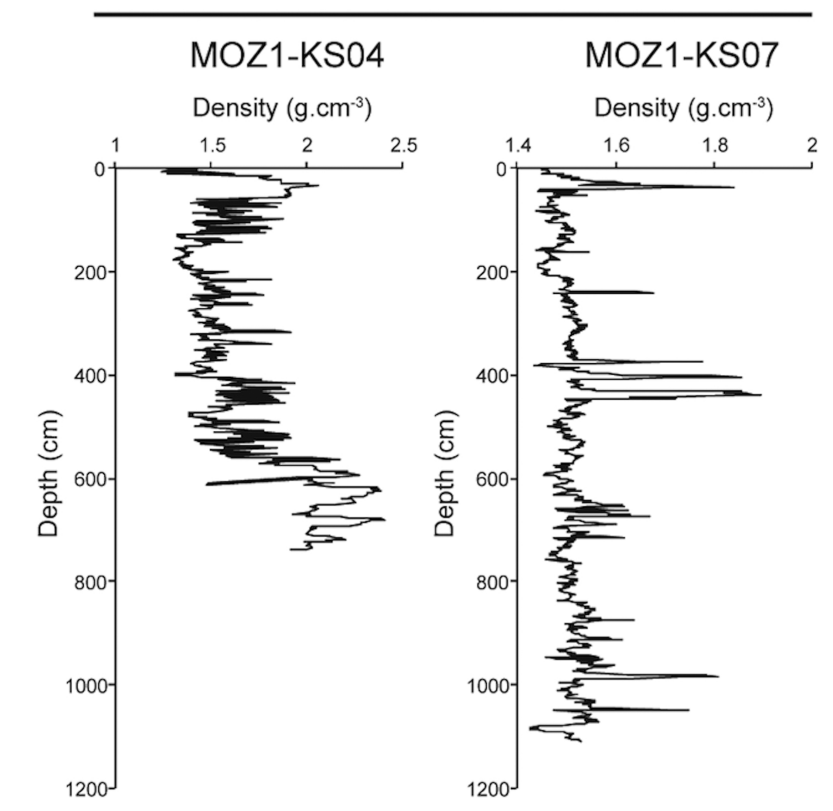

GLORIEUSES PLATFORM

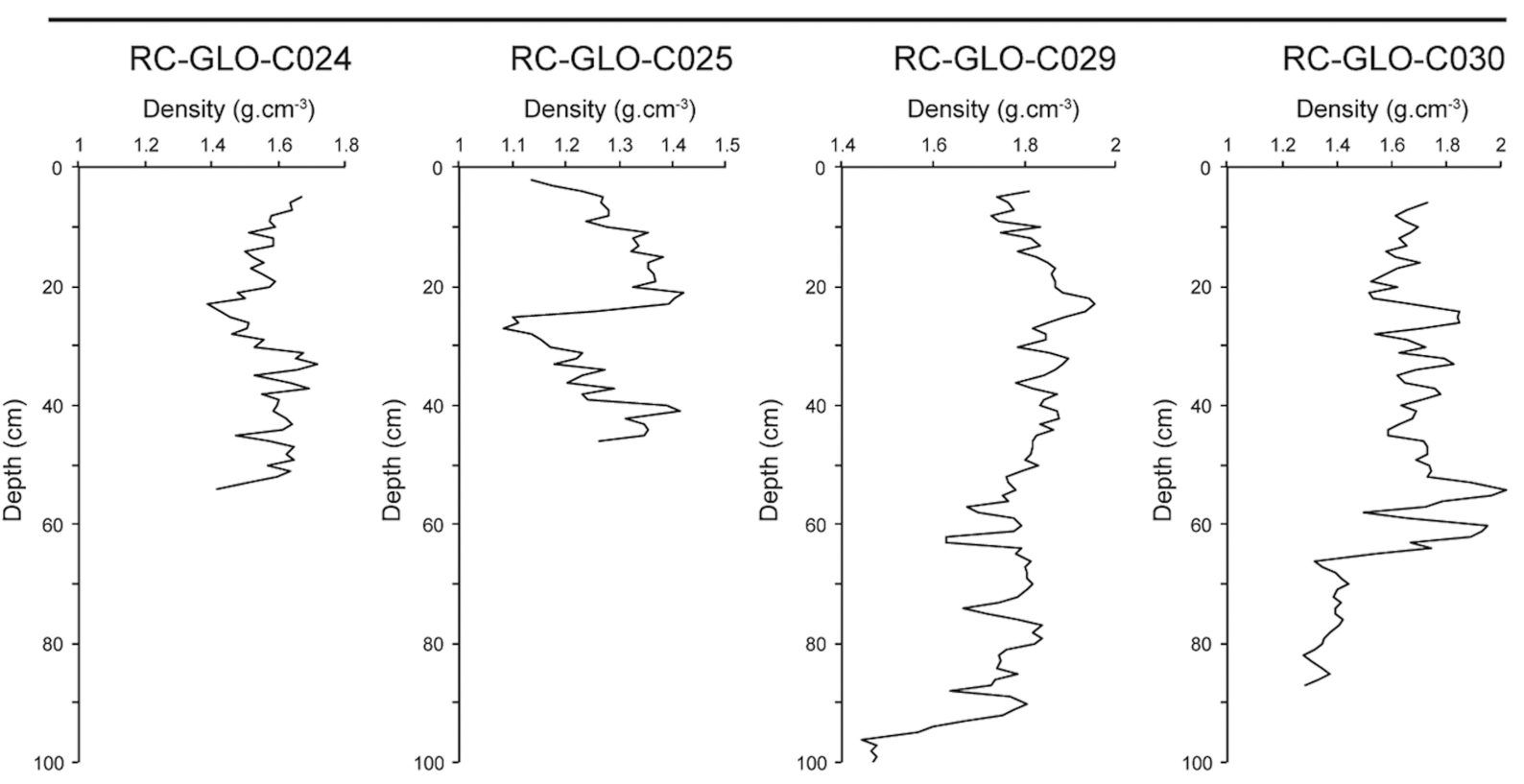




\section{carbonate platform production $0.57 \mathrm{~km}^{3}$ (0-10ka)}
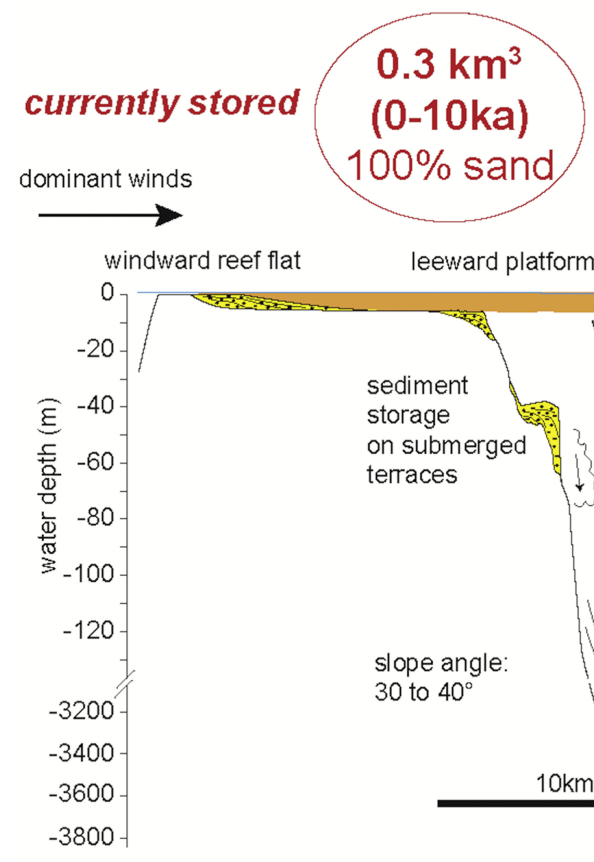

leeward platform edge

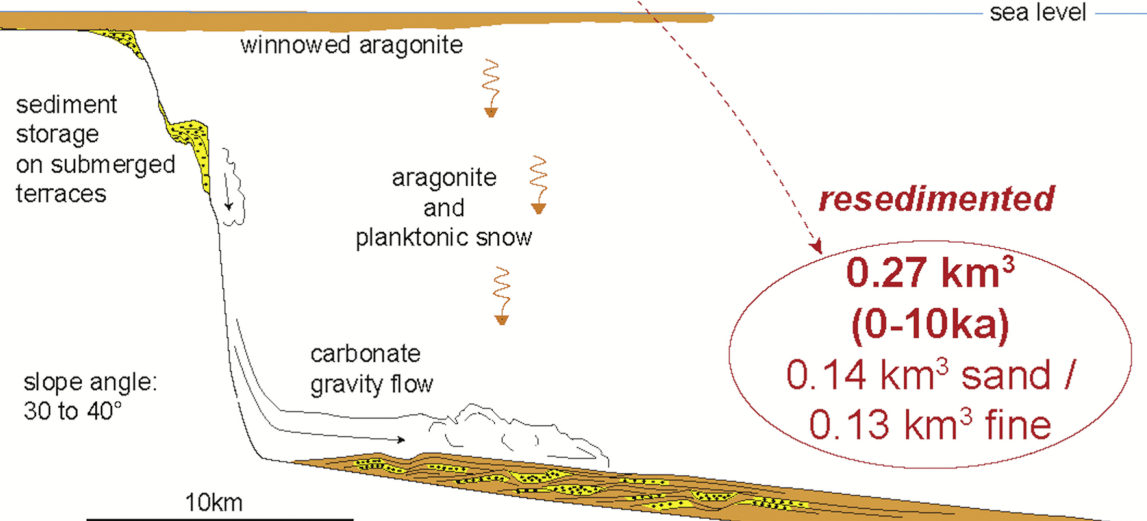



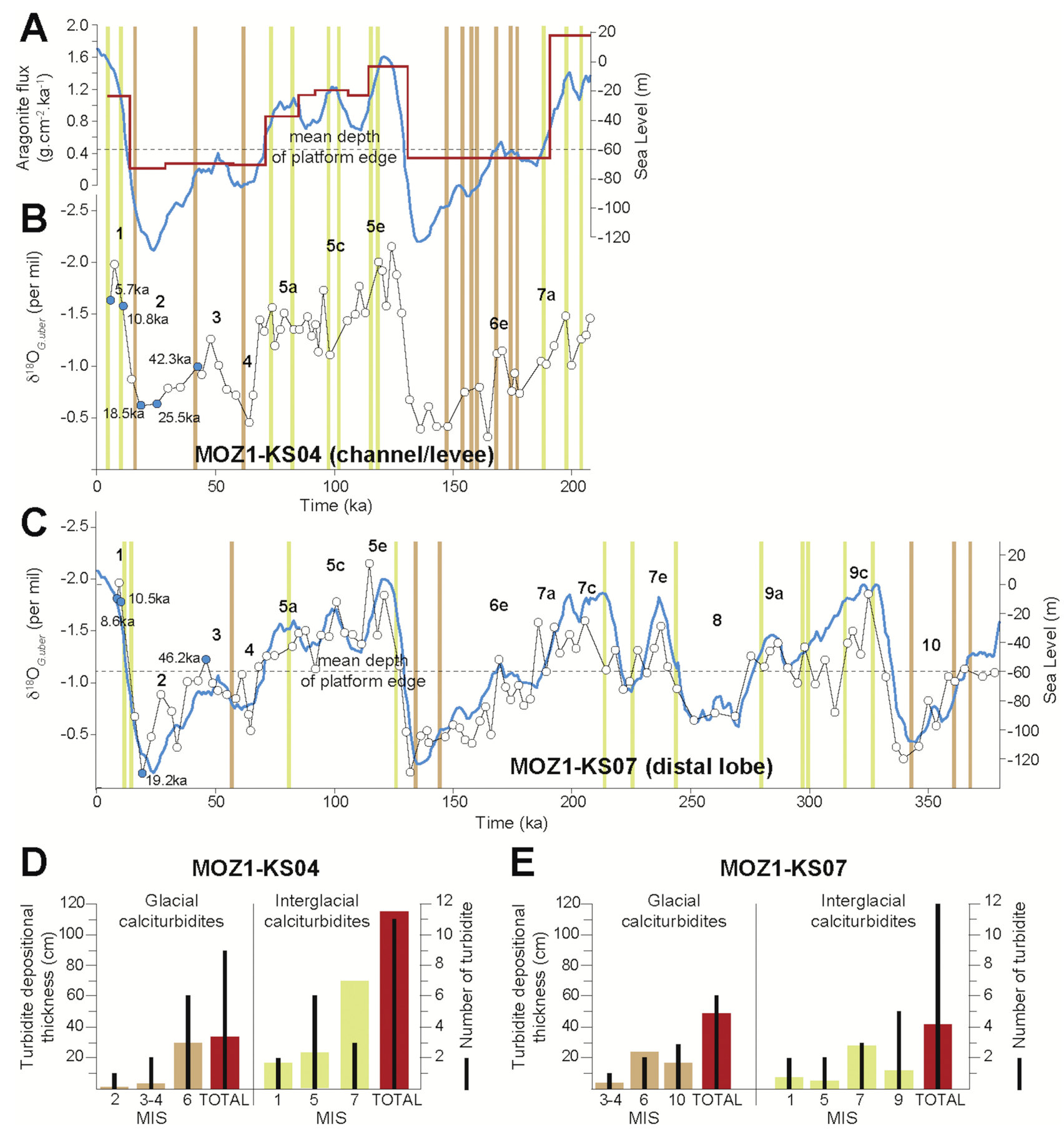

Figure 10 